\title{
Landforms Evolution of Wadi Qudaid Area, West Central Arabian Shield, Saudi Arabia: An Example of the Role of the Geological Factors in the Urban Extensions
}

\author{
Ali A. Mesaed ${ }^{1,2}$, Mohammed A. M. Alghamdi ${ }^{3}$, Abdullah R. Sonbul ${ }^{3}$ \\ ${ }^{1}$ Geo-Exploration Techniques Department, Faculty of Earth Sciences, King Abdulaziz University, Jeddah, KSA \\ ${ }^{2}$ Geology Department, Faculty of Sciences, Cairo University, Giza, Egypt \\ ${ }^{3}$ Engineering and Environmental Geology Department, Faculty of Earth Sciences, King Abdulaziz University, Jeddah, KSA \\ Email: alimesaed@yahoo.com,mmushrif@gmail.com,dr.asonbul@yahoo.com
}

How to cite this paper: Mesaed, A.A., Alghamdi, M.A.M. and Sonbul, A.R. (2020) Landforms Evolution of Wadi Qudaid Area, West Central Arabian Shield, Saudi Arabia: An Example of the Role of the Geological Factors in the Urban Extensions. Open Journal of Geology, 10, 612-640.

https://doi.org/10.4236/ojg.2020.106028

Received: May 12, 2020

Accepted: June 13, 2020

Published: June 16, 2020

Copyright $\odot 2020$ by author(s) and Scientific Research Publishing Inc. This work is licensed under the Creative Commons Attribution International License (CC BY 4.0).

http://creativecommons.org/licenses/by/4.0/

cc) (i) Open Access

\begin{abstract}
Wadi Qudaid is located in the west central part of Saudi Arabia. It about 135 $\mathrm{km}$ to the northeast of Jeddah city along Al Haramein highway and it represents the upstream of the very large alluvial plain along the Red Sea coast. It runs in NE direction parallel to many wadis of the west central part of Saudi Arabia i.e. Wadi Fatima, wadi Sitarah. The wadi floor is filled by Quaternary deposits which represent good groundwater aquifer. Geologically, the present-day residual landforms of Wadi Qudaid are composed mainly of Precambrian Arabia shield rocks overlained by Tertiary sedimentary rocks and finally harrat (Tertiary volcanic). The Precambrian rocks are represented by 1) a lower layered basic and intermediate volcanic and the intercalated volcaniclastics. This unit is correlatable with Samran Group, 2) an upper layered acidic volcanic and the intercalated acidic volcaniclastics. The Arabian shield rocks are intensively folded and dragged along the major NE faults. They are directly overlain by Tertiary basic volcanic (harrat) and the related volcanoclastic red beds). The main geomorphologic elements of the study area include plateau, scarps, and the wadi floor. The plateau is represented by the black basaltic sheet that contains some semi-rounded depressions filled with Quaternary eolian sands. The scarps of the main wadi and its tributaries are nearly steep and contain many asphaltic roads with some isolated cone hills detached from the scarps. Geomorphological, Wadi Qudaid represents the incomplete erosion cycle that begins with the formation of deep galleries and very steep and narrow wadies formed along the major NE faults and related fractures and folds. The progress of the erosion processes led to the formation of narrow interfluves as a result of pedimentation and sculpturing of
\end{abstract}


the wadies sides by scarp retreat. The peniplanation stages of the erosion cycles are reached in the southwestern and the central part of the wadi where fast peniplained areas were formed. The results of this study revealed the role of the different geological processes (lithology, structural elements and climatic conditions) in the distribution of present-day human populations in urban extensions. Qudaid, Dhubaya-Jumah, Dabyah, Al Khamrah, Almansa and Al Massamah are the main villages of Wadi Qudaid area.

\section{Keywords}

Wadi Qudaid, Geomorphology of Saudi Arabia, Landforms Evolution, Erosion Cycle, Urban Extensions

\section{Introduction}

\subsection{Literature Review}

Wadi Qudaid is occupied by many villages and contains a lot of green private farms. The present-day human population of Wadi Qudaid area depends on the private and governmental wells. The area is of good climate in the winter, but it is very hot in the summer periods. The geomorphology, hydrology and drainage morphometry of Jeddah-Makkah district appears in the publications [1]-[8]. The climate of Jeddah Governate is a hot arid desert type, with some rainfalls in the spring season; the temperature reaches a maximum of $49^{\circ} \mathrm{C}$ within the period between March and August, and a minimum of $17.3^{\circ} \mathrm{C}$ during the period between January and February. The groundwater of Wadi Qudaid area is suitable for agriculture purposes and the results of the chemical analyses show the normal content of $\mathrm{Ca}, \mathrm{Mg}, \mathrm{Na}, \mathrm{Cl}, \mathrm{SO}_{4}$, and $\mathrm{HCO}_{3}$ [9]. They also concluded that the groundwater aquifer of the northeastern part has shallower depths than in the southern part and the Quaternary deposits are thinner in the northeastern part than the southern part (downstream). The study also revealed that the groundwater is of good quality in the upstream (NE) area than the downstream (SW).

\subsection{Aims of the Study}

This present study aims to give a detailed description of the different landforms of Wadi Qudaid area. Also, the study deals with the clarification of the different geomorphologic processes that resulted in the formation and evolution of the landforms of the study area. The second aim of this study is to clarify the role of the different geological factors in the human populations and urban extensions in the study area.

\subsection{Methods of the Study}

This study is based on detailed field measurements and descriptions of the different landforms. Global mapper and Arc GIS programs are used in the preparation of the satellite images and geologic maps as well as the topographic and 
contour maps. The results of the study are combined together with drawing different geomorphologic models illustrating the landforms' evolutional history.

\subsection{Geologic Setting}

The study area is of characteristic geologic and geomorphologic setting. It represents a part of the Arabia shield rocks of the west central part of Saudi Arabia (Figure 1). It contains many NE trending wadies i.e. wadi Fatima, Wadi Qudaid, and wadi Sitarah. Wadi Ashamiyah and wadi Ashumaysi are NW trending (Figure 1). The geology of Makkah area is described by [10] to include older basement rocks which overlay, by the sedimentary rocks, then the volcanic rocks

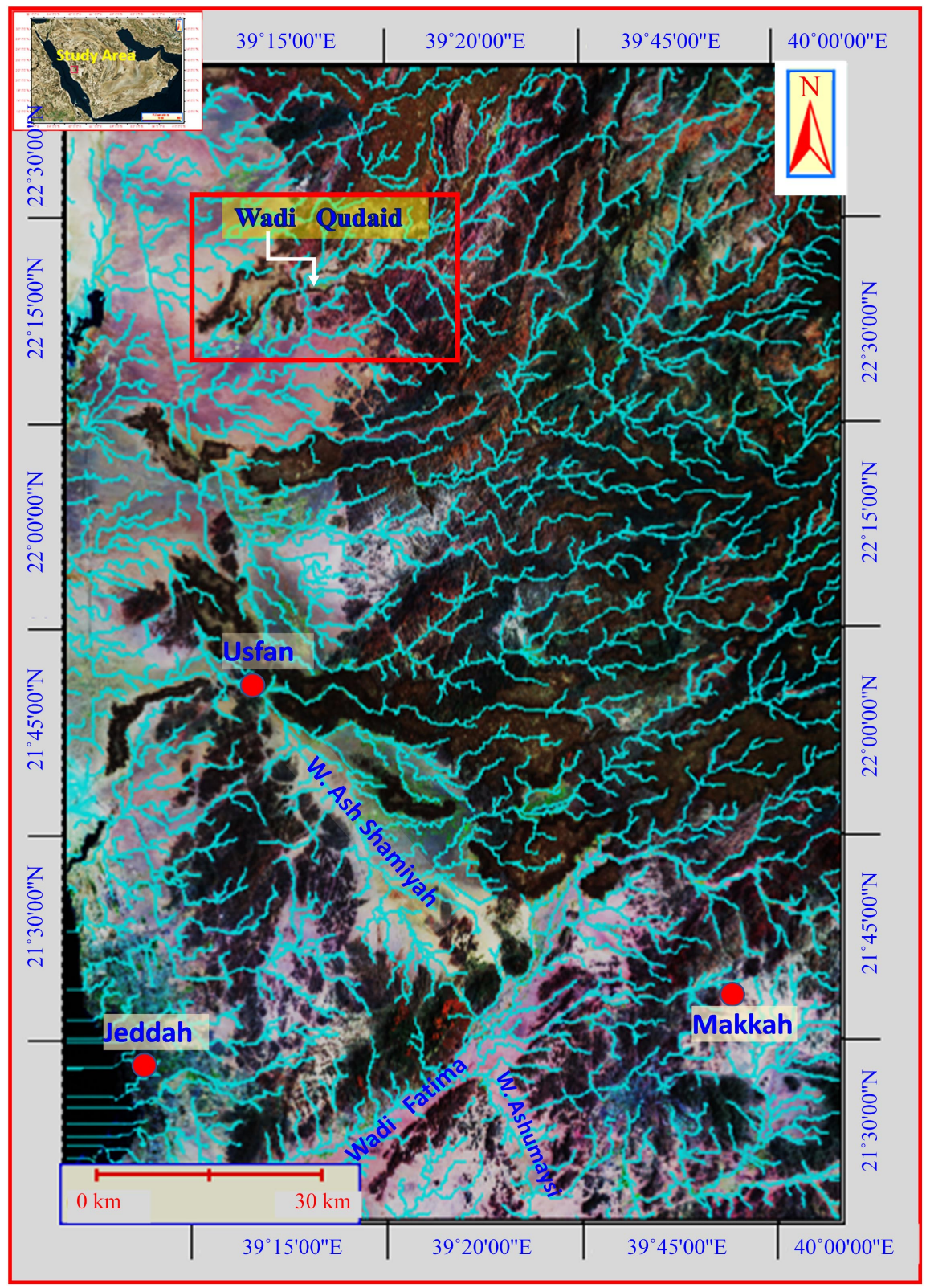

Figure 1. Mr. Said satellite image of Makkah districts showing the general physiography and drainage lines and the location of Wadi Qudaid. 
(basalt 2 older and basalt, younger) and finally the Quaternary deposits which are subdivided into five types (Figure 2). According to the Arabian shield map [11], the study area comprises four main geologic units: 1) The Arabian shield rock units which are composed for igneous and metamorphic rocks (Figure 3); 2) Tertiary sedimentary succession which is present just underlying the Precambrian Arabian shield rocks which are presented by slope-forming unit of intercalations of clays, sandstones, siltstones and sandstones; 3) Tertiary harrat which consists mainly from basic volcanic of basalt, dolerite amygdaloidal and vesicular basalts. This unit forms the uppermost black horizontal sheet on the submit of most of landforms, and 4) Quaternary wadi deposits which form the floor of Wadi Qudaid and the small tributaries of Wadi Qudaid (Figure 1). These deposits are composed mainly of gravels, sands, silts and clays. The groundwater of the study area is mainly recorded within these deposits.

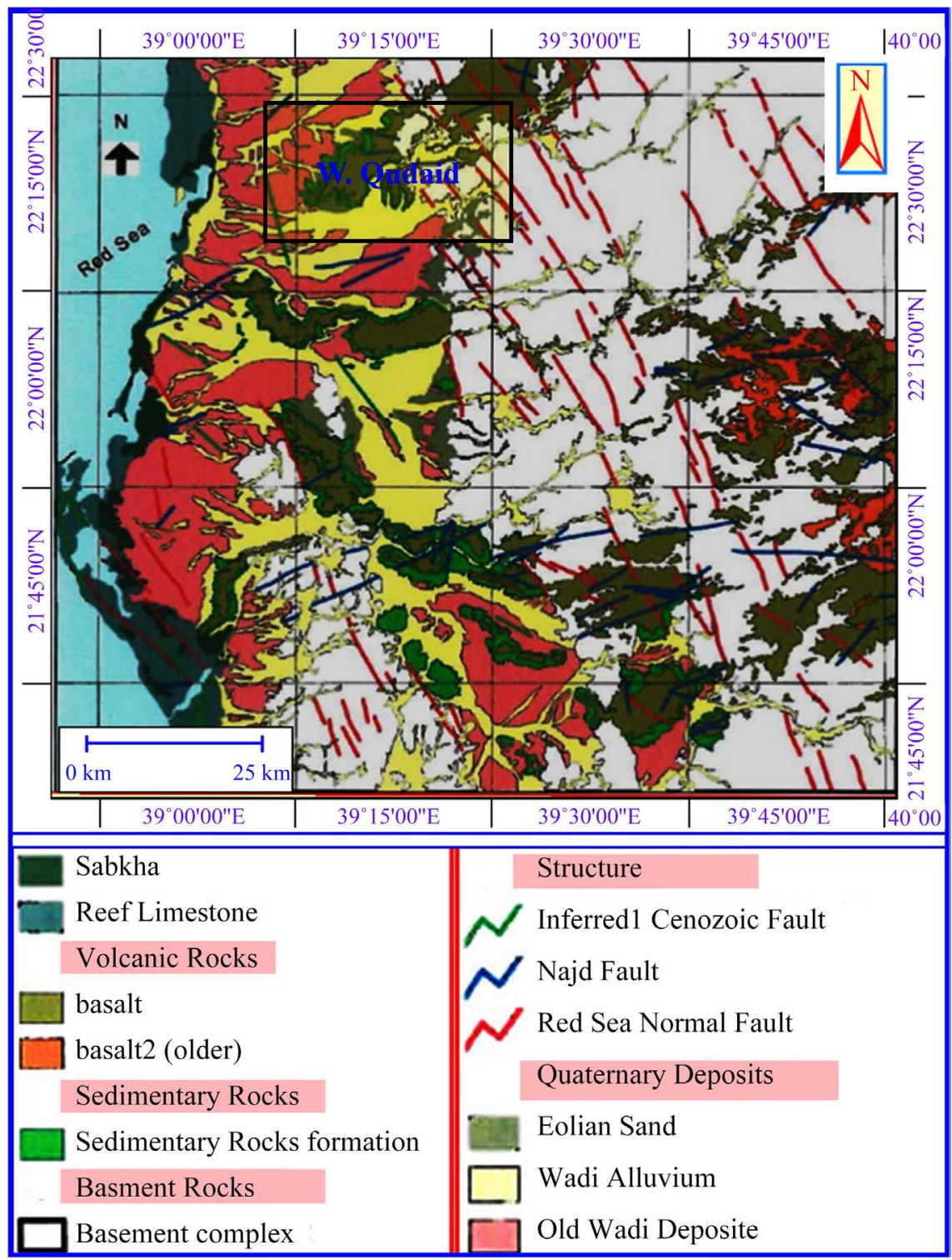

Figure 2. Geologic map of Makkah districts showing the different rock units [10]. 


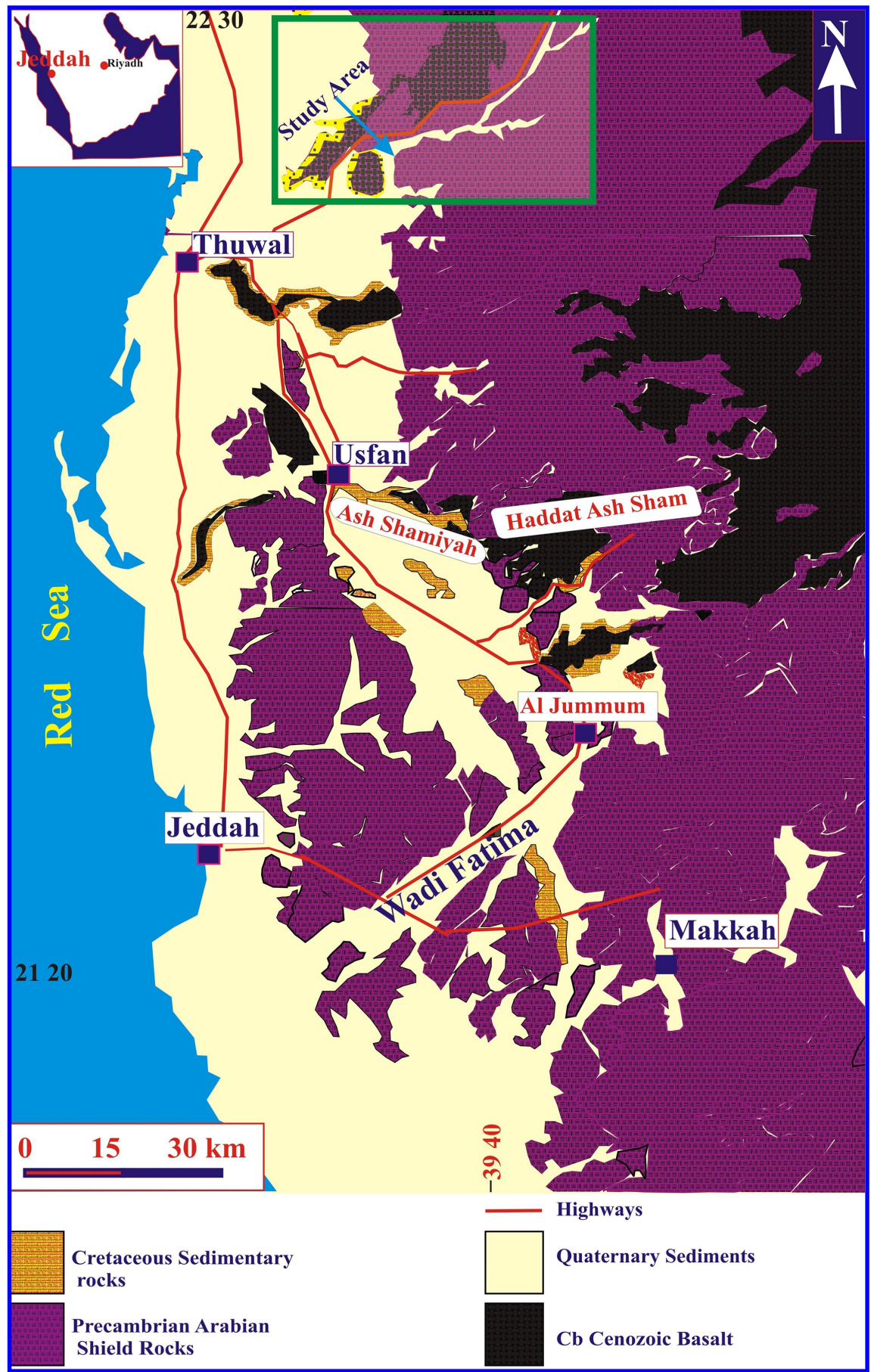

Figure 3. Geologic map of Makkah districts showing the different rock units and the main asphaltic roads [11].

The Arabian shield rocks are present in two subunits: 1) lower metamorphosed basic volcanic and the intercalated volcaniclastics (Figure 4(A)). This unit is present in the southern part of Wadi Qudaid and, 2) Acidic volcanic and the intercalated marble deposits which are present in the central and northern (upstream) part of Wadi Qudaid. It overlies the green schist and amphibolites of the above-mentioned unit and underlies the Tertiary volcanics (harrat) or Ter- 
tiary sedimentary succession of Usfan Formation (Figure 4(B), Figure 4(C)). This unit is composed of interbedded rhyolite, rhyolitic tuffs, chert, and quartz bands (Figure $4(\mathrm{C})$ ). Thin black basic bands are present within the middle and upper part of the succession (Figure 5(A)). White color carbonates and/or quartz bands are also present (Figure 5(A)). The Tertiary sedimentary succession is composed of volcaniclastic red beds, sandstones, siltstones, basalts, and carbonates (Figure 5(B)). This unit is of characteristic color and it is excavated
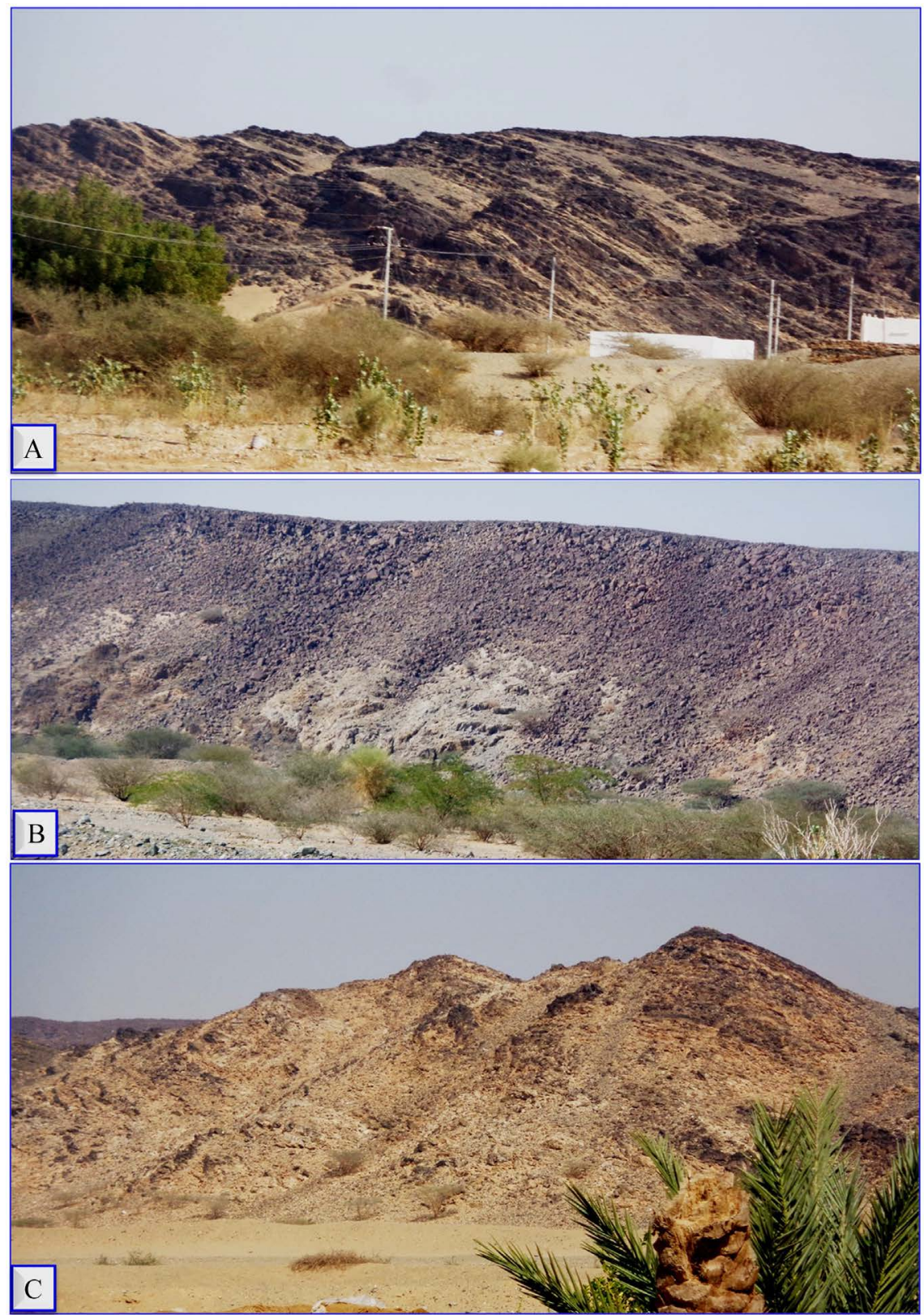

Figure 4. (A) The black metamorphosed rocks (green schists and amphibolites) of Samaran Group (basic volcanic and the associated volcaniclastics of unit 1); (B) Unit 2: acidic volcanic and the associated volcaniclastics of unit 2 (lower light color part of the photo) and the overlying black basalt (harrat) (upper part of the photo); (C) Folded acidic volcanic and the associated volcaniclastic of unit 2. 

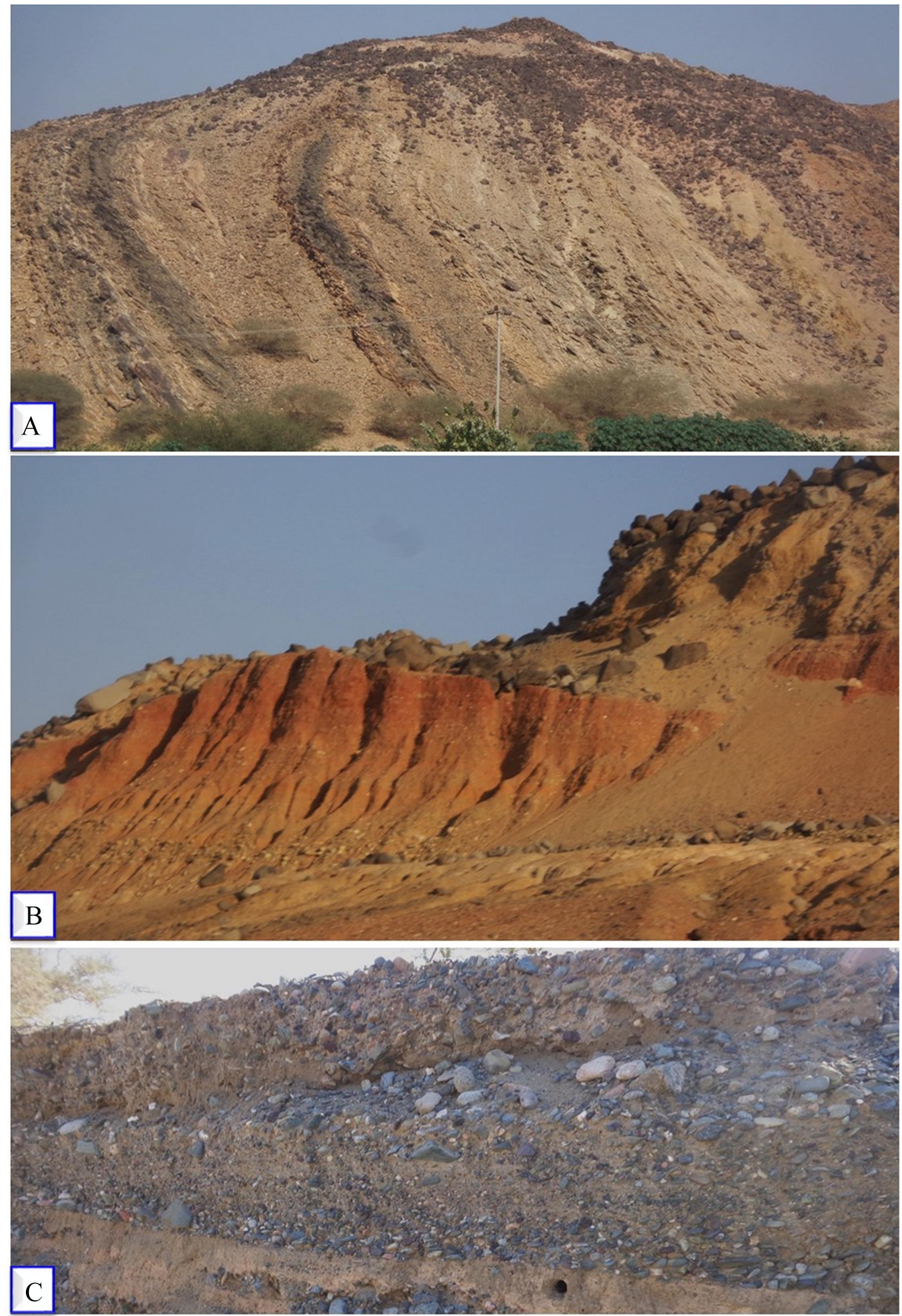

Figure 5. (A) The black ad light zones of the acidic volcanic and the associated volcaniclastics unit 2, the northern part of Wadi Qudaid; (B) Volcaniclastic red beds of the Tertiary sedimentary succession just underlying the basalt (Harrat); (C) Alluvial fan conglomerates of the wadi fill deposits of Wadi Qudaid.

for foundation purposes in Qudaid city. The Tertiary basalt (harrat) which covers the submits of most of the landforms of the study area (Figure 4(B)). It consists mainly of basalts and intercalated glassy basalts. The Quaternary wadi deposits which are composed of gravels, sandstones, siltstones and varicolored clays (Figure $5(C)$ ). Clays of these deposits represent the suitable soils for cultivation and the formation of the farms and villages of Qudaid area. 


\subsection{Structural Elements of Wadi Qudaid}

The structural elements of Makkah district have previously been studied by many authors. [12] studied the area between Jeddah and Al Taif and concluded that the area is subdivided in terms of geology into two units. These are the Precambrian basement, which is built up by intrusive series and layered rocks and the Tertiary to Quaternary basaltic effusives. They also concluded that the region has been affected by various periods which, on one hand, have to be addressed to Precambrian orogeneses and on the other, to the Tertiary-Quaternary motions in connection with the Red Sea rifting. They also pointed out that, the Satellite Image Map (SIM) shows ENE-trending fractures of Jeddah/Taif area as "first order lineaments" of Precambrian origin (Figure 6). According to this study, the SIM interpreted NNW Red Sea Rift Fractures as first order lineaments and the bending of the NNW trend is clearly visible on this map. Regional considerations suggest that NNE fractures of the area belong to the conjugate set Tertiary fractures.

The study area is dominated by NE lineaments [12] (Figure 6). The structural elements of the study area into faults that are related to the red sea tectonics other three main types of fault sets affecting the Precambrian crystalline rocks [10] [13]. These sets have N-NW, NE, and E to NE trends. He recommends the avoidance of these fault systems in locating the potential sites of radioactive disposal sites.

\section{Geomorphology of Wadi Qudaid}

On the satellite images, the study area represents an ideal example for the etched or excavated areas. W. Qudaid is recharged from many tributaries from the eastern and northeastern parts of the study area (Figure 7(A)). Within its course, it runs in E-W direction, especially in the lower part and in NE direction in the upper part (upstream). The present-day landforms are either represented by Arabian shield rocks, Tertiary sedimentary succession, Tertiary basalts (harrat), and finally Quaternary deposits (Figure 7(B)).

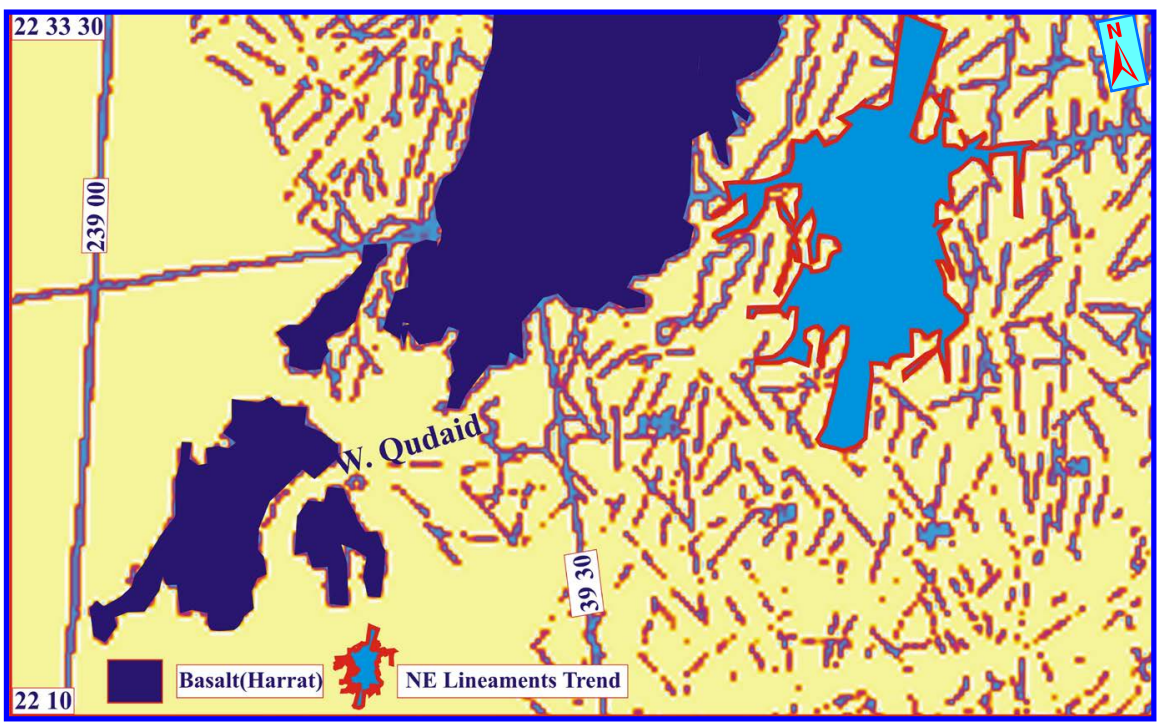

Figure 6. Lineament map of Wadi Qudaid area [12]. 


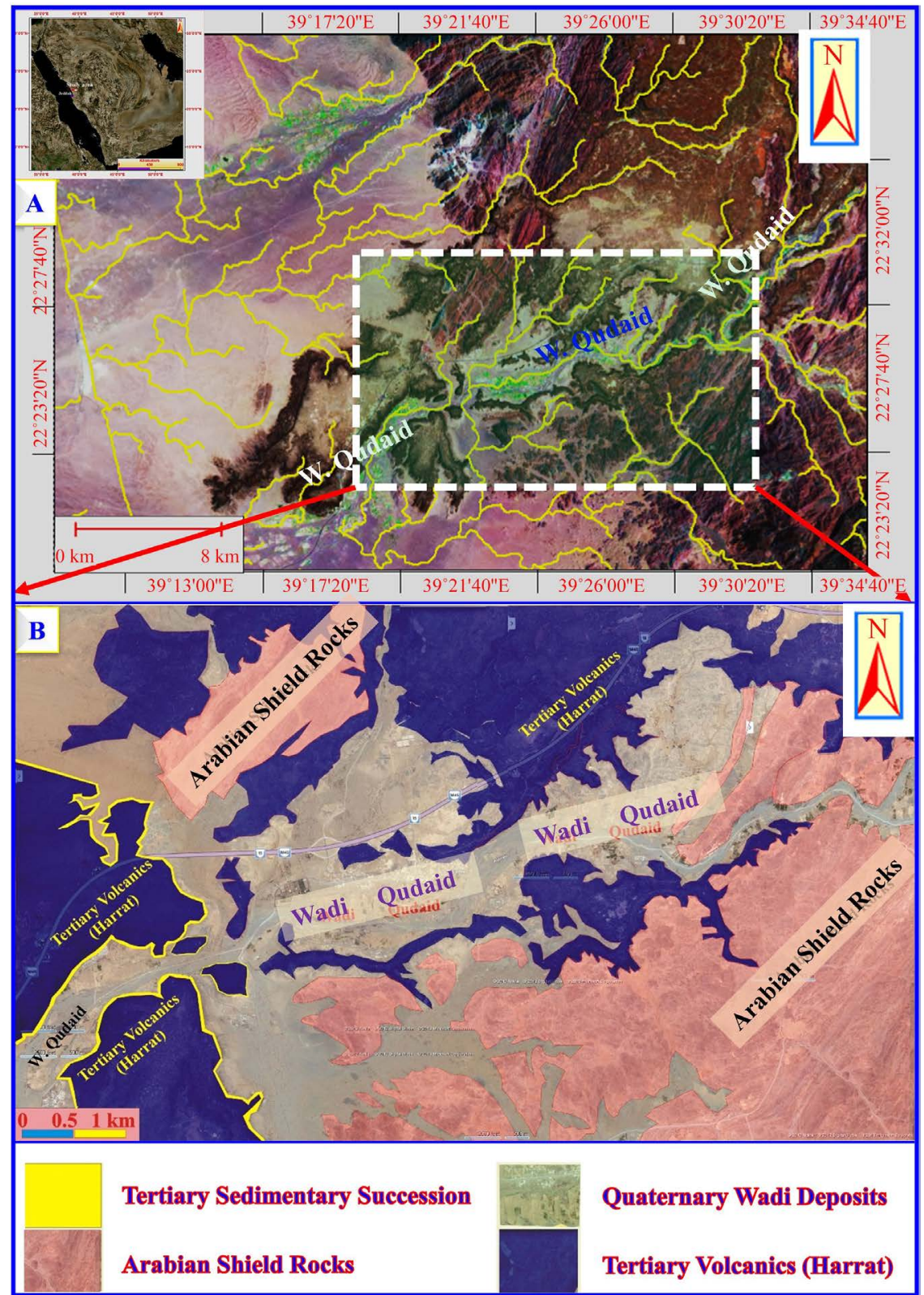

Figure 7. (A) Main drainage lines (small tributaries) of the central and northern part of Wadi Qudaid; (B) Simplified geologic map of the main rock units of Wadi Qudaid area designed in the Google image.

\subsection{Geomorphology of Southern Sector}

This part of Wadi Qudaid represents the downstream of the wadi. It is highly denudated and sculptured where the residual land forms percentage do not exceed $40 \%$ of the total volume of rocks (Figure $8(\mathrm{~A})$, Figure $8(\mathrm{~B})$ ). The relicts landforms take different forms and sizes according to the degree of weathering and denudation. The shapes and sizes of these landforms depend mainly upon the intensity of weathering and sculpturing processes, which is variable from one area to another one. These processes depend on the variation in topography, rock types, and intensity of structural elements. All the landforms are nearly having 
the same elevation and also the same slope elements. The progress of weathering processes and evaluation of the different landforms is shown below as follow:

1) The different geomorphologic units in the study area

2) The Flat Plateau

Which form the main geomorphologic unit where it is present as flat-topped areas of Arabian shield rocks overlain by the black Tertiary basaltic rocks (harrat) (Figure 9(A)). Some large areas of the Arabian shield rocks are not overlained by harrat and these domains are not flat-topped. The progressive desiccation of this plateau (Figure $9(B)$ ) led to the formation of v-shaped areas surrounded by low-lying cone hills (Figure 9(B)).

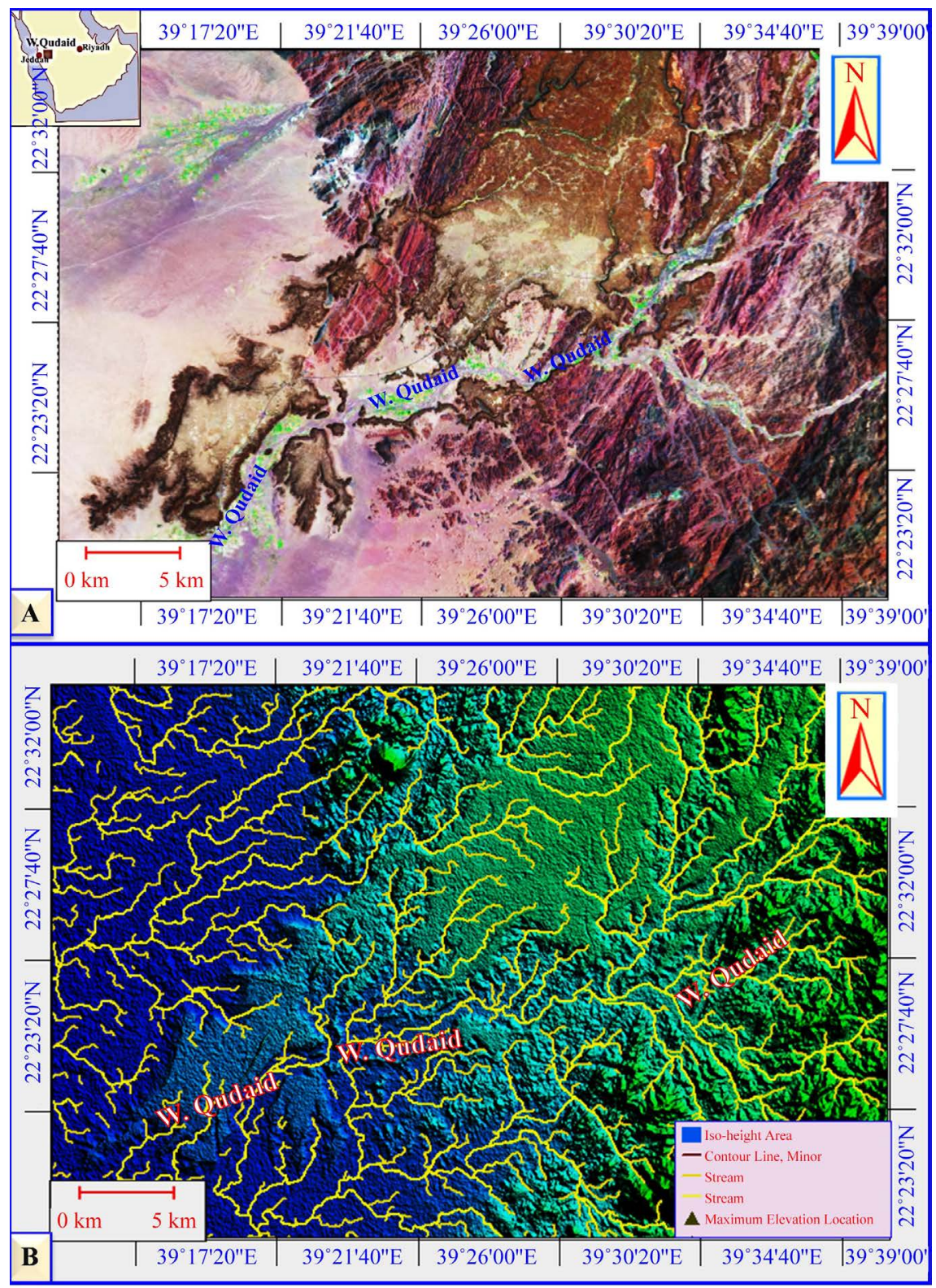

Figure 8. (A) Regional Mr. Said satellite image showing the residual landforms of Wadi Qudaid; (B) The drainage lines of the central, northern, and southern part of Wadi Qudaid. 


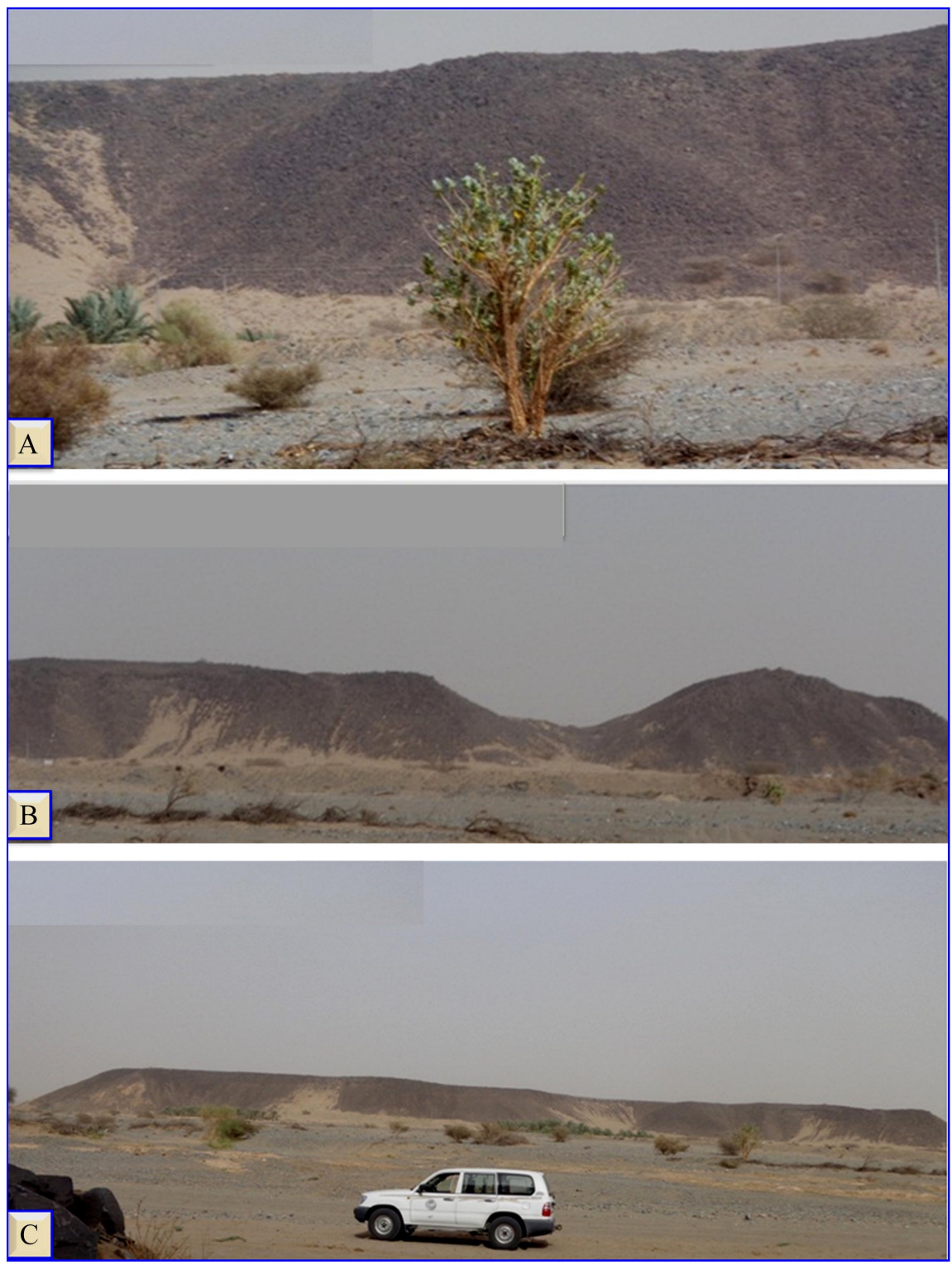

Figure 9. (A) The main plateau on both sides of Wadi Qudaid that capped by the Tertiary basalt (Harrat); (B) Initial stages of desiccation and formation of v-shapes on the tops of flat-topped plateau; then the formation of isolated cone hills; (C) Progressive corrosion of the cone hills by scarp retreated (peneplanation) and formation of wide depression (the car).

\section{3) Cone hills and depressions}

The progress of the weathering processes led to the development of small depressions (Figure 9(C)) surrounded either by flat-topped platen or by isolating cone hills. These depressions are either on the floor composed mainly of Quaternary Wadi fill deposits or by rubbles and boulders from the surrounding platen. Many of these depressions are surrounded by irregular scarps that contain many promontories along which asphaltic are present (Figure 10(A)). Toward the upstream of Wadi Qudaid, many isolated cone hills are present, which results from incomplete stages of denudation (Figure 10(B)). 


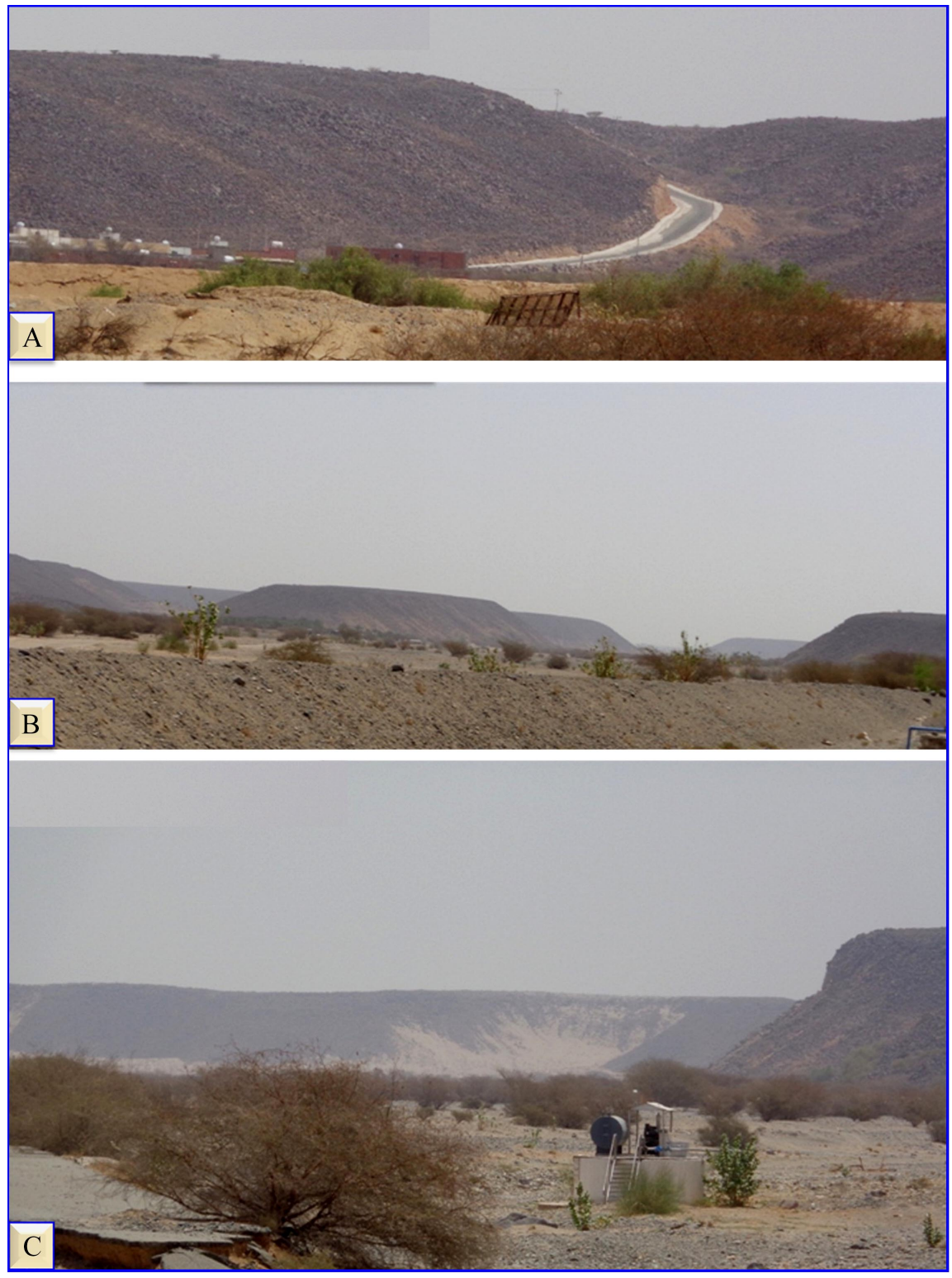

Figure 10. (A) Asphaltic road on the promontory on the scarp on the western flank of Wadi Qudaid; (B) Isolated cone hills and table lands formed during the middle stages of weathering and denudation; (C) Destructed asphaltic road on the main course of Wadi Qudaid by the effect of recent sheet floods.

The floor of the Wadi is filled by Quaternary deposits of different sheet flood episodes which resulted in the destruction of the recent asphaltic road of the study area (Figure 10(C)). The loamy soil of Wadi Qudaid area is formed from flood plain clays and silts. Many private farms are present on these loamy flood plain silts and clays.

4) Slope Analysis

The slope analyses of the land forms of the study area revealed the presence of four main slope elements (Figure 11(A)). These are the upper convexity on the topmost part of the isolated landforms, the vertical (cliff) slope, the rectilinear 
(straight) slope, and finally the pediment (lower concavity). The presence of these four slope elements reflects the formats of these landforms by progressive and subsequent stages of weathering.

5) Sculpturing and denudation

The progress of these processes led to the landform evaluation of the study area. The structural elements have a very clear role in the evolution of the landforms where they interplay with the different folds and faults (Figure 11(B)) which led to the exposing of different rock units.

\subsection{Geomorphology of the Central and Northern Sectors}

In this part, the wadies become narrow and the interfluves become wider. The total volume of the residual landforms is very high. The interfluves are very narrow and very deep (Figure 12(A), Figure 12(B)). The recharge area is located in the east and northeast. The elevation of wadi floors is slightly higher than those

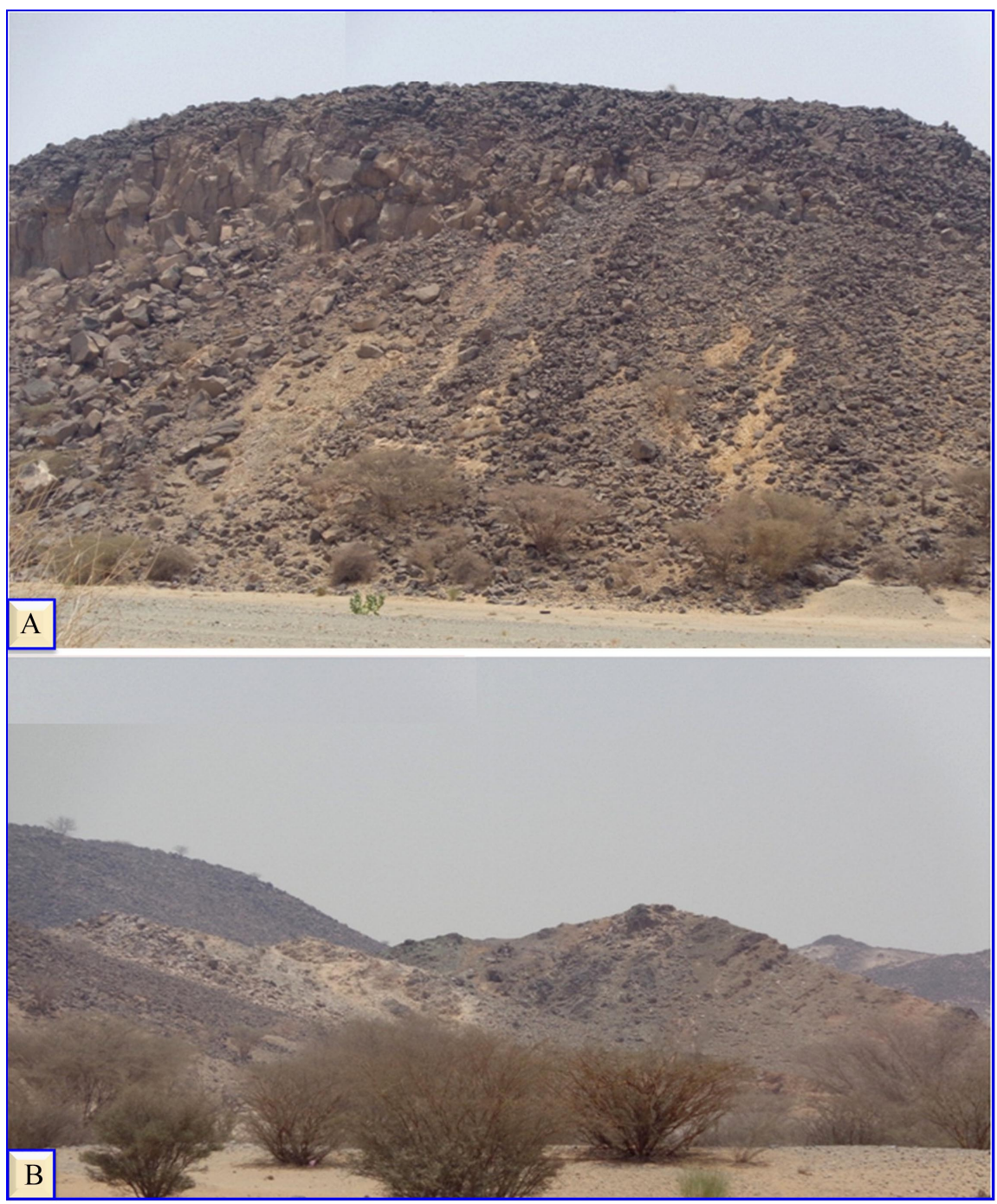

Figure 11. (A) The four main slope elements in the different landforms of Wadi Qudaid area; (B) Block faulting and disturbance of the different rock units. 


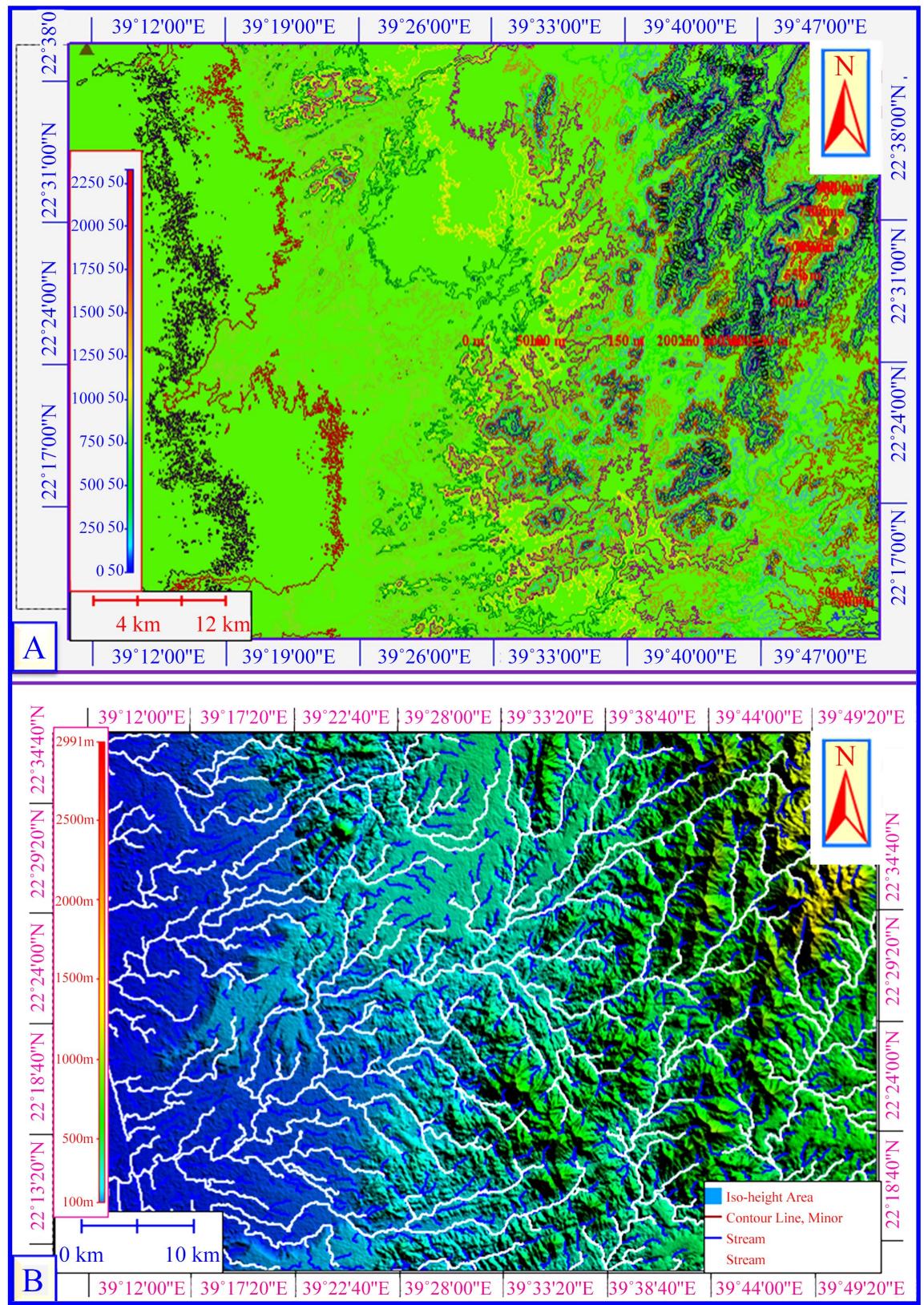

Figure 12. (A) Topographic contour image of Wadi Qudaid showing the presence of small residual landforms on the downstream part has the same elevation of the upstream parts of the study area (red colors in the elevation legend of (A)); (B) Regional elevation image showing the tributaries and interfluves of northern (upstream) (recharge) are of Wadi Qudaid.

of the southwestern part in the downstream areas. The topographic contour image of Wadi Qudaid showing the presence of small residual landforms on the downstream part has the same elevation of the upstream parts of the study area (red colors in the elevation legend of Figure 12(A)).

1) Landforms

In the upstream areas, the landforms are semi rounded, where the residual landforms comprise two main units i.e. lower straight (rectilinear slope which is 
present on the acidic volcaniclastic unit and upper convexity (Topmost harrat). The regional elevation image showing the tributaries and interfluves of the northeastern part (upstream, recharge) are of Wadi Qudaid (Figure 12(B)). In some cases, the topmost black hard cap becomes steeper. In some denudated areas, the basaltic hard cap becomes slightly weathered and the cone hills become more rounded. In more advanced stages, the cone hills become progressively sculptured and a new wider shape was formed in a new stage of downward migration of the water table. Ultimate stages of sculpturing led to the widening of the $\mathrm{V}$-shape and formation of wide interfluves by the side-retreat of the scarp. In the southern part of Wadi Qudaid area, some villages are constructed in the resulted wide areas (Figure 13(A)) in the western part of the N-S part of Wadi Qudaid. The contour maps of this part show the low topography of wide areas that are suitable for the human population and urban extension (Figure 13(B)).

The progressive of this form of weathering led to the evolution of landforms by the scarp retreated and lowering of elevation as a result of the complete erosion of the hard-resistant basaltic cap (Figure 13(B)). This will be followed by peneplanation processes and complete removal of the residual landforms and formation of wide peneplaned areas of low topography and suitable for the human population (Figure 13(B)). These areas are now filled by the Quaternary deposits which represent groundwater aquifer and represent the suitable cultivated lands of Wadi Qudaid area.

\section{- Scarps of the Plateau}

These scarps surround the wide interfluves of the main course of W. Qudaid. In some areas of the northeastern part of Wadi Qudaid (Figure 14(A)), there is a wide area suitable for the urban extensions on both sides of the wadi (Fig $14(\mathrm{~A})$ ). These areas are progressively denudated by the formation of very narrow wadies along main faults and fractures within the scarps (Plateau, Figure 14(B)). The progress of sculpturing processes by the side retreat of the scarps of the interfluves led to the formation of wide areas suitable for the human population (Figure 14(C), Figure 15(A)).

These interfluves areas are of rounded and symmetric slope. The slope analyses of these landforms revealed these processes of one rectilinear slope unit with a high angle in its lower part. In highly denudated areas, the lower part of the rectilinear slope becomes eroded giving rise to lower concave slope (pediment, Figure 15(B), Figure 15(C)) which is associated with the formation of some promontories in the scarps. In some landforms, the rectilinear slope is present either on the two units of the Arabian shield rocks (Figure 16(A), Figure 16 (B) or on the Tertiary sedimentary succession just underlying the harrat. This unit is intensively excavated for clay deposits which are used in road pavements and in cement industry (Figure 16(C)).

The scarps represent the main geomorphologic unit of the study area. The wadi floor is surrounded from all directions by scarp. It rises at different elevations from the wadi floor, ranging from 40 to $60 \mathrm{~m}$. It is concluded that this scarp is erosional, resulting from slope evolution by parallel retreat. The scarp 
exhibits the classical four hill side slopes of [14] and separates the two main erosion surfaces of the study area (old erosion surface, Harrat on top) and younger erosion surface (the floor of the wadi). The most striking feature of the scarp is the occurrence of a number of fan-shaped embayment and dry stream channels. Smaller channels also cut into this scarp and the rock pediments on the floor of the wadi. Lateral erosion by stream floods was probably responsible for the formation of these embayments, where upland valleys debouch into the low lands of the wadi floor. A continuous slope retreat led to the gradual reduction of the upland masses and formation of prominent projections in the scarps of Wadi Qudaid.

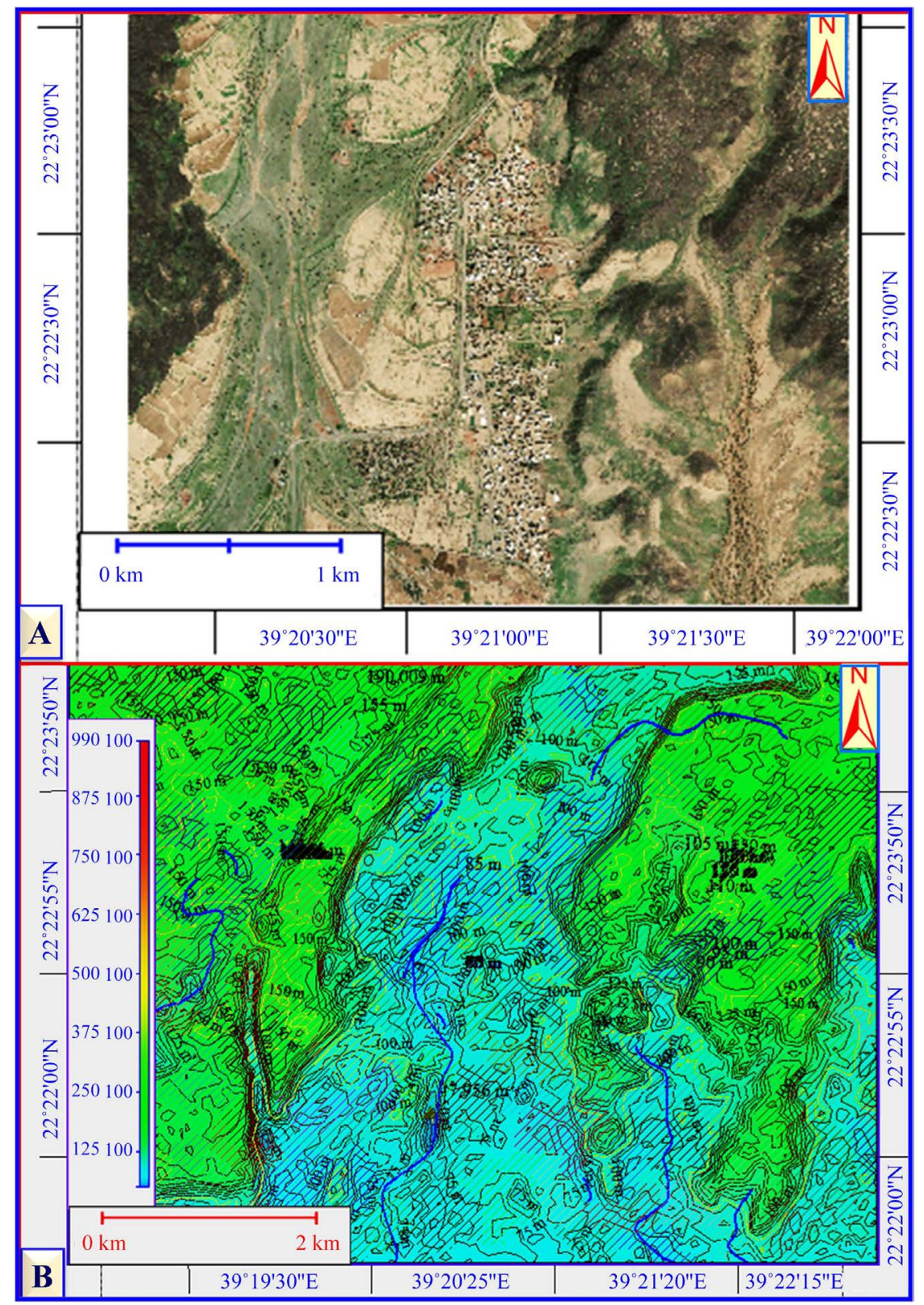

Figure 13. (A) Satellite image showing the urban extension in the wide peneplain area of the southern part of Wadi Qudaid; (B) Contoured image of the (A) showing the presence of the human populations in the southern part of Wadi Qudaid. 


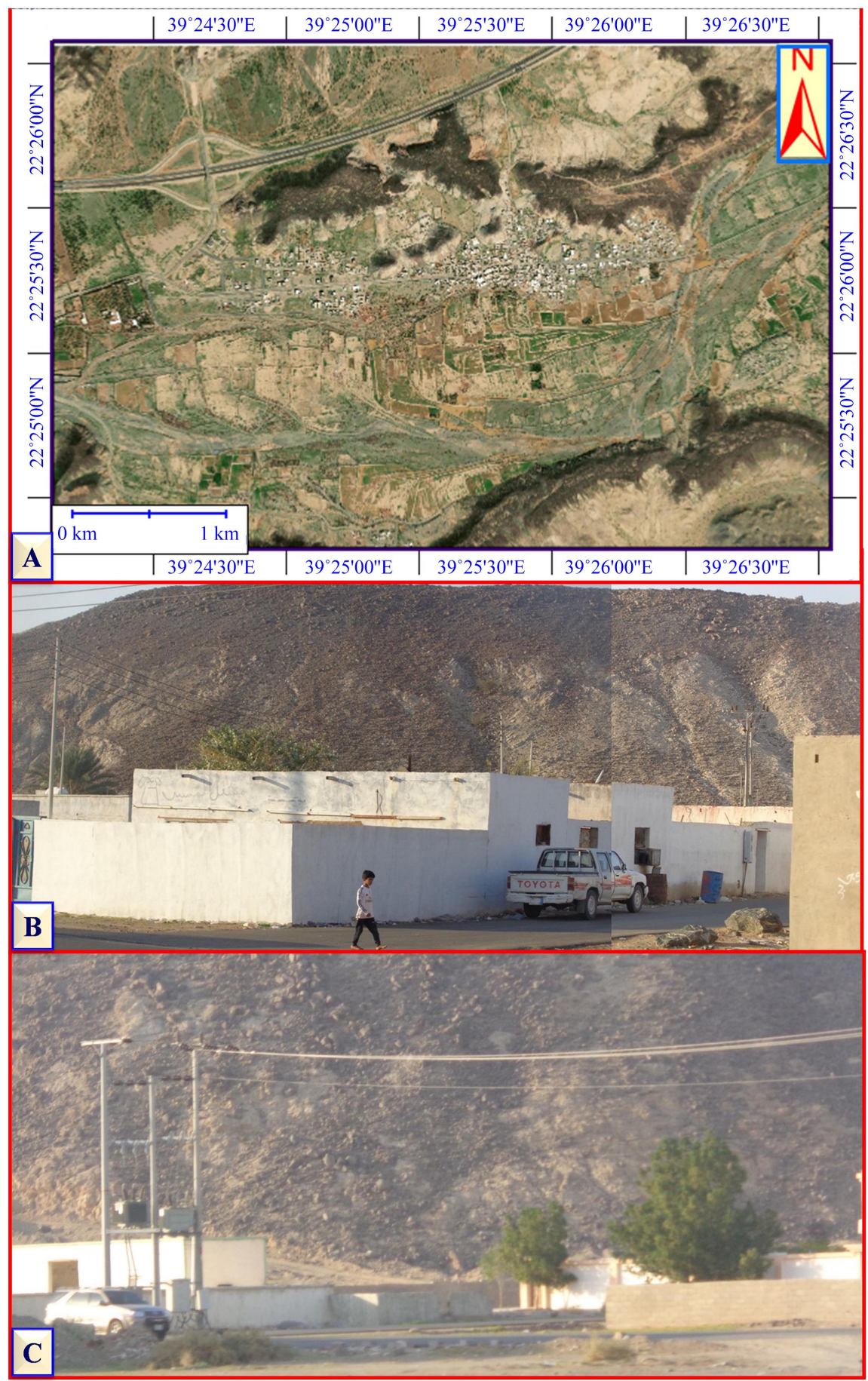

Figure 14. (A) Satellite image showing the urban extension in the wide peneplain area of the northern part (Al Mogamaa area) part of Wadi Qudaid; (B) The vertical slope unit (cliff) associated with the topmost hard basaltic cover just overlying the straight slope unit (white color in the lower part of the photo); (C) Progressive destruction of the basalt of the hard cap and the formation of lowland areas suitable for the human population.

\section{Course (floor) of Wadi Qudaid}

The geomorphology of Wadi Qudaid floor is mainly controlled by arid climates (windy conditions) which led to wind erosion (wind abrasion and defla- 
tion) which are represented by 1) polishing of the rock surfaces where they become smooth, pitted or furrowed; 2) scouring and grooving of the soft sits and clays and formation of lag deposits by gradual removal of the loose and fine-grained particles leaving behind oriented boulders and gravels.

\section{Landforms Evolution}

The term landforms evolution has been used by many authors to describe the changing and evolution of the geomorphologic phenomenon. The landscapes are dynamic, acutely sensitive to natural and artificial perturbation and they can

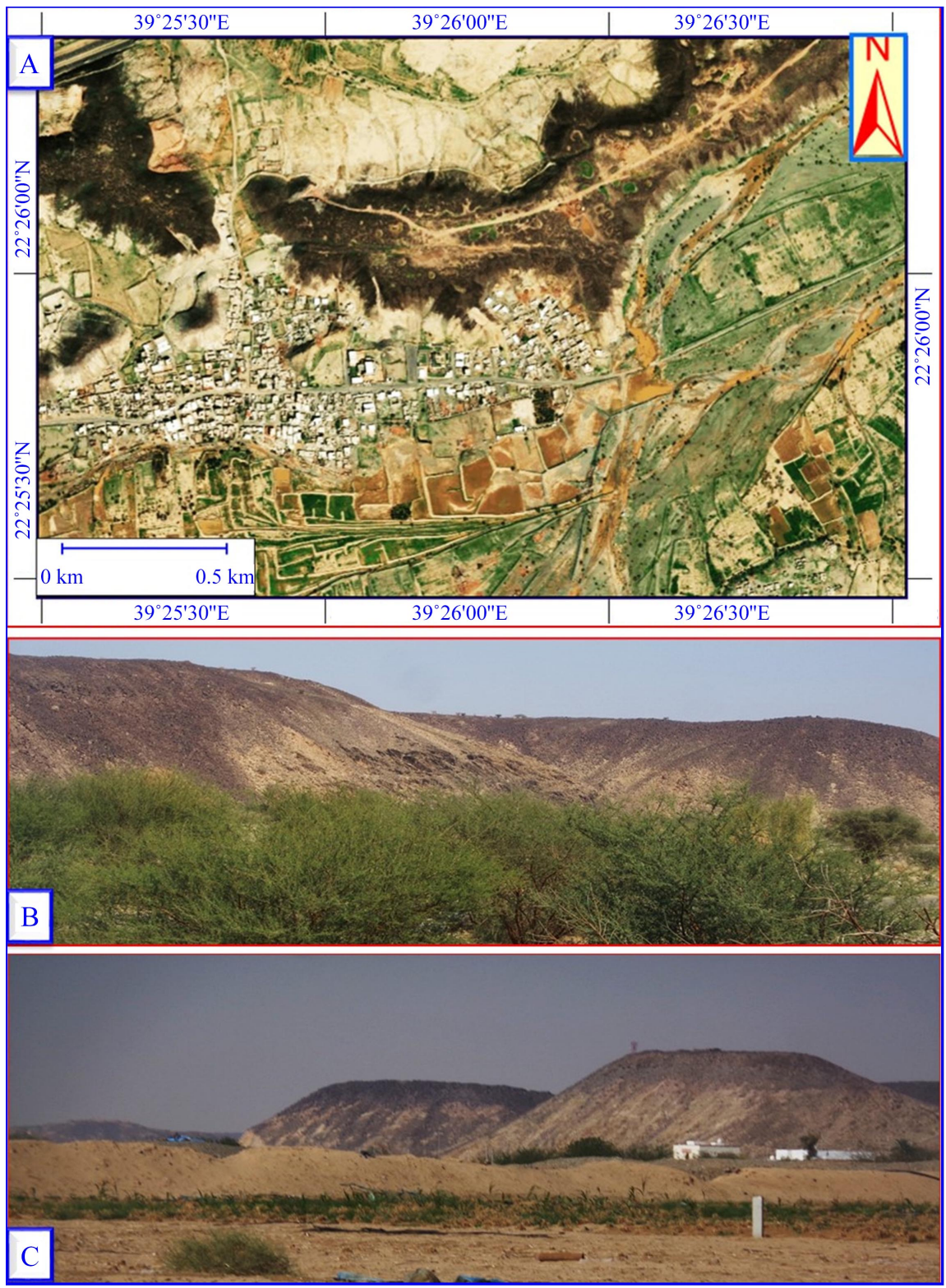

Figure 15. (A) Satellite image of the human population in the wide areas of the northern part of Wadi Qudaid; (B) Formation of narrow deep wadies with wide interfluves in between; (C) Ultimate stage of denudation and formation wide wadies and narrowly rounded interfluves (cone hills). 


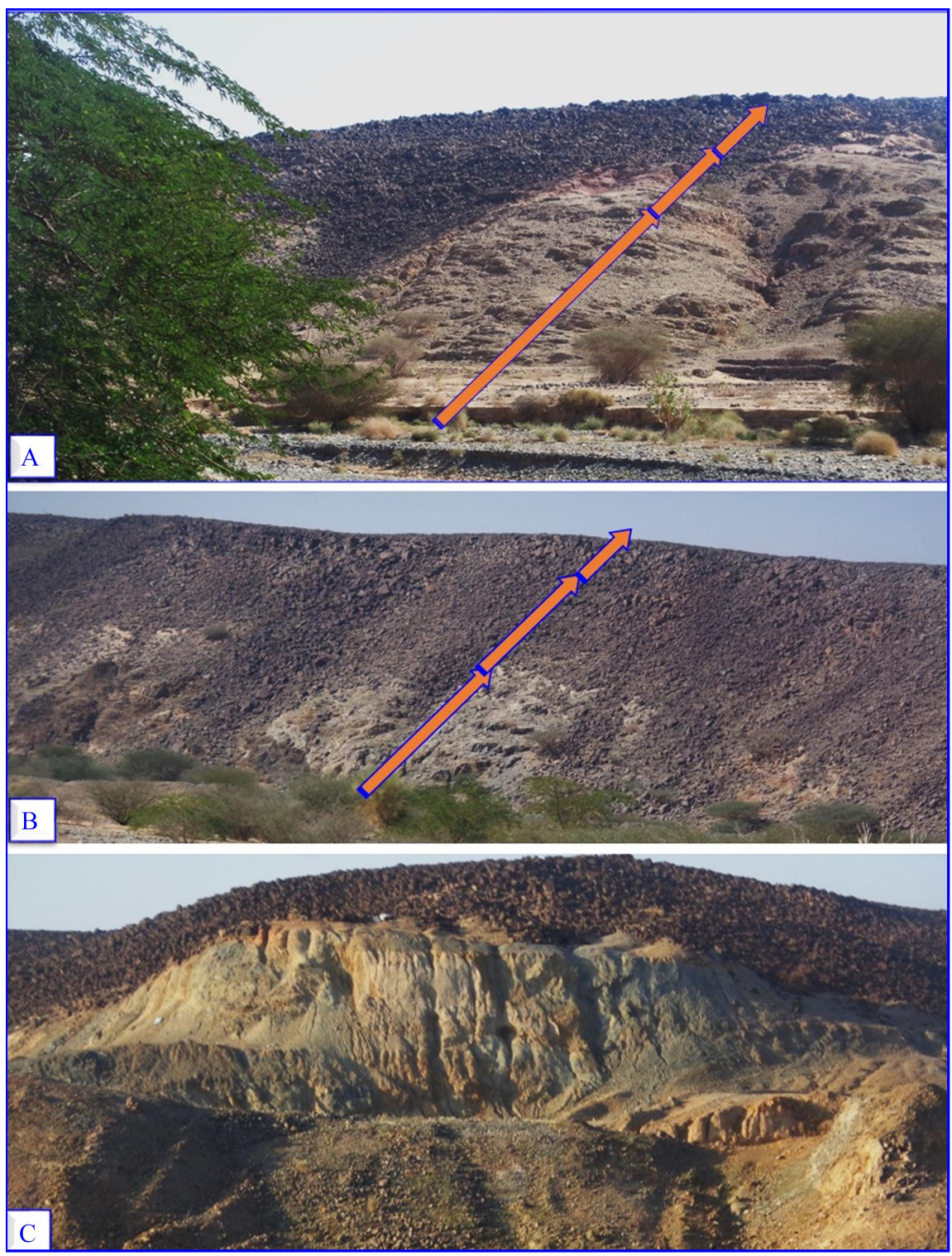

Figure 16. (A) (B) The rectilinear (straight) slope of the sides of the interfluvial areas is associated with the white acidic volcanics and the associated volcaniclastic (lower part of photos); (C) The rectilinear slope unit on the Tertiary sedimentary succession just underlying the harrat and contains the clay deposits.

evolve through a succession of stages to a plain of low relief [15]. He also pointed out that, the progression of an erosion cycle is interrupted by tectonic or environmental changes; thus, many landscapes preserve vestiges of earlier cycles useful in reconstructing the recent history of Earth's surface. Landforms are bounded by slopes, so their evolution is best understood through study of slopes and the complex of factors controlling slope character and development. The substrate, biosphere, climatic environment, and erosive processes are principal factors.

Each landform has its own physical shape, size, materials and is a result of the action of certain geomorphic processes and agent(s). Actions of most of the geo- 
morphic processes and agents are slow, and hence the results take a long time to take shape. Landforms once formed may change in their shape, size and nature slowly or fast due to continued action of geomorphic processes and agents. Each and every landform has a history of development and changes through time. In humid regions, which receive heavy rainfall running water is considered the most important of the geomorphic agents in bringing about the degradation of the land surface. There are two components of running water: the first one is the overland flow on the general land surface as a sheet, the second one is the linear flow as streams and rivers in the valleys. Most of the erosional landforms made by running water are associated with vigorous and youthful rivers flowing over steep gradients. With time, stream channels over steep gradients turn gentler due to continued erosion, and as a consequence, lose their velocity, facilitating active deposition.

Wadi Qudaid is present in the western part of Saudi Arabia within the Arabian shield rocks. It trends in NE direction parallel to many other wadies i.e. Wadi Fatima and wadi Sitarah. The study area represents the part of the Precambrian old ocean basin (more than 600 million years). This basic and acidic volcano-sedimentary succession and the related magmatic intrusion were formed during that time. After the Precambrian time, Arabian shield rocks were uplifted and become a positive area until the last 40 million years (Oligocene-Miocene). During this time the Arabian Shield rocks are subjected to block faulting and folding and intensive weathering and erosion. In the Oligo-Miocene times, fluvial and fluvio-marine conditions were dominated in the west central part of Saudi Arabia. This led to the deposition of the Tertiary sedimentary succession of Ashumaysi, Haddat Asham, Usfan, and Khulaysi formations. During the time of deposition of the upper parts of these formations, rift-related volcanic activities were dominated associated with the opening of the Red Sea. During the latter times, the different rock units were subjected to folding and faulting and formation of many fractures and weak planes (Figure 17(A), Figure 18(IA), Figure 18(IB)). During humid, rainy periods, the flood water migrates downwards in very fine, narrow and steep galleries. Streams are few during this stage with poor integration and flow over original slopes showing shallow V-shaped valleys with no floodplains (Figure 18(IC)). This stage is represented in the northeast upland (upstream, recharge) areas of Wadi Qudaid. The rocks of this area are represented either by the layered volcaniclastic rocks of the Arabian Shield or the black basic volcanic rocks (harrat). The incision of rivers with gradual dissection and etching of basaltic sheet and the underlying Tertiary sedimentary succession by slope and scarp retreat (Figure 17(B)). During humid rainy periods, the progressive weathering and lateritization led to the formation of very steep and narrow wadies cross-cutting in the tectonized areas (initial stages of etchplanation, Figure 18(IB), Figure 18(IC); Figure 19(Ib1), Figure 19(Ib2) and Figure 19(Ic1), and Figure 19(Ic2)).

The wide interfluves were formed as a result of the continuous slope retreat 
and the gradual consumption of the black hard basaltic cap of the formed landforms (Figure 17(B)). The presence of the basaltic caps with nearly the same thickness all over the small as well as the large isolated cone hills and ridges and the presence of talus and scree from the basaltic fragments along the slopes and of the residual landforms and along the main scarps of Wadi Qudaid indicates the

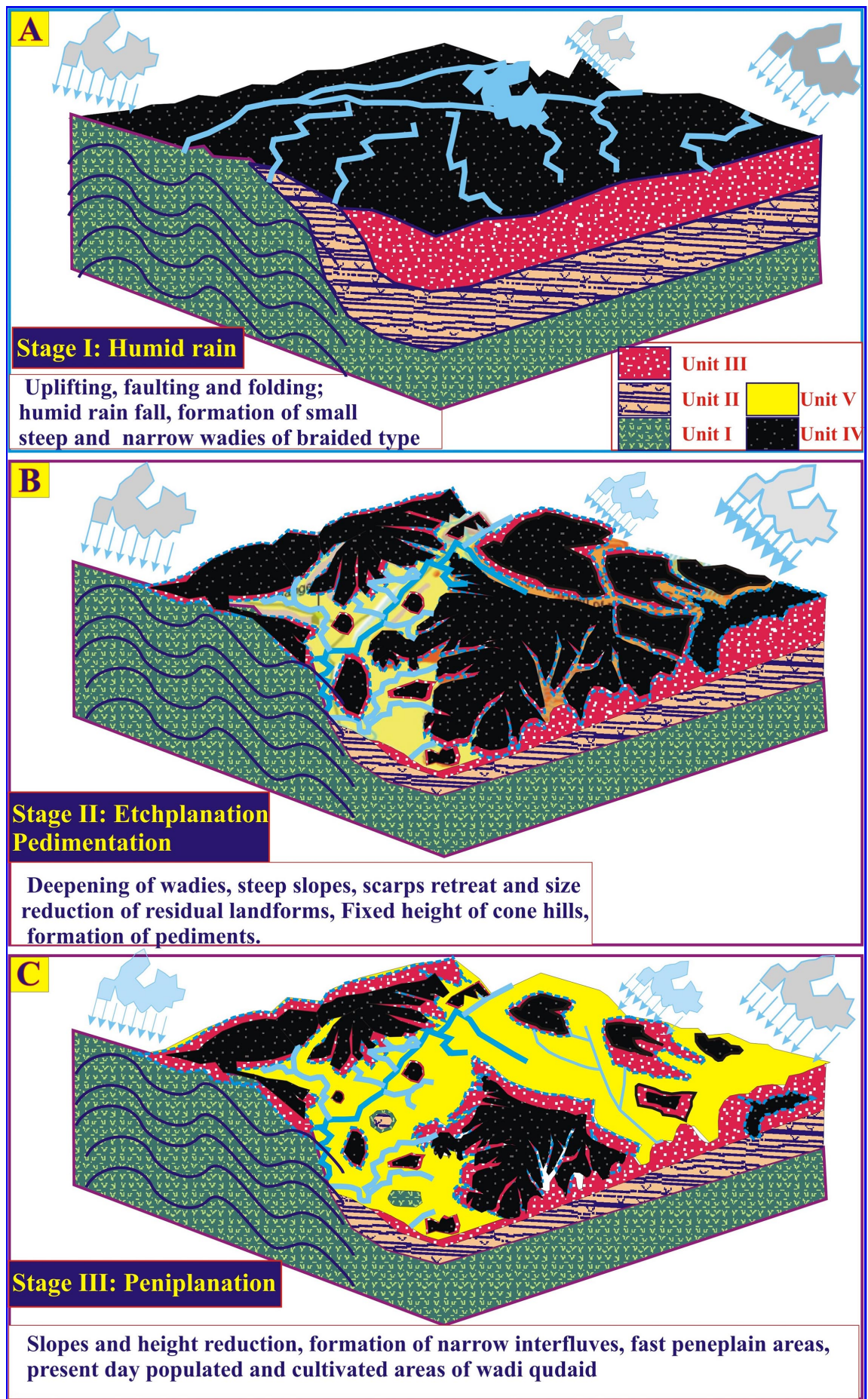

Figure 17. (A) Humid Rainfall stage in the landforms evolution of Wadi Qudaid area; (B) Etchplanation and pedimentation stages; (C) Peneplanation Stage. 


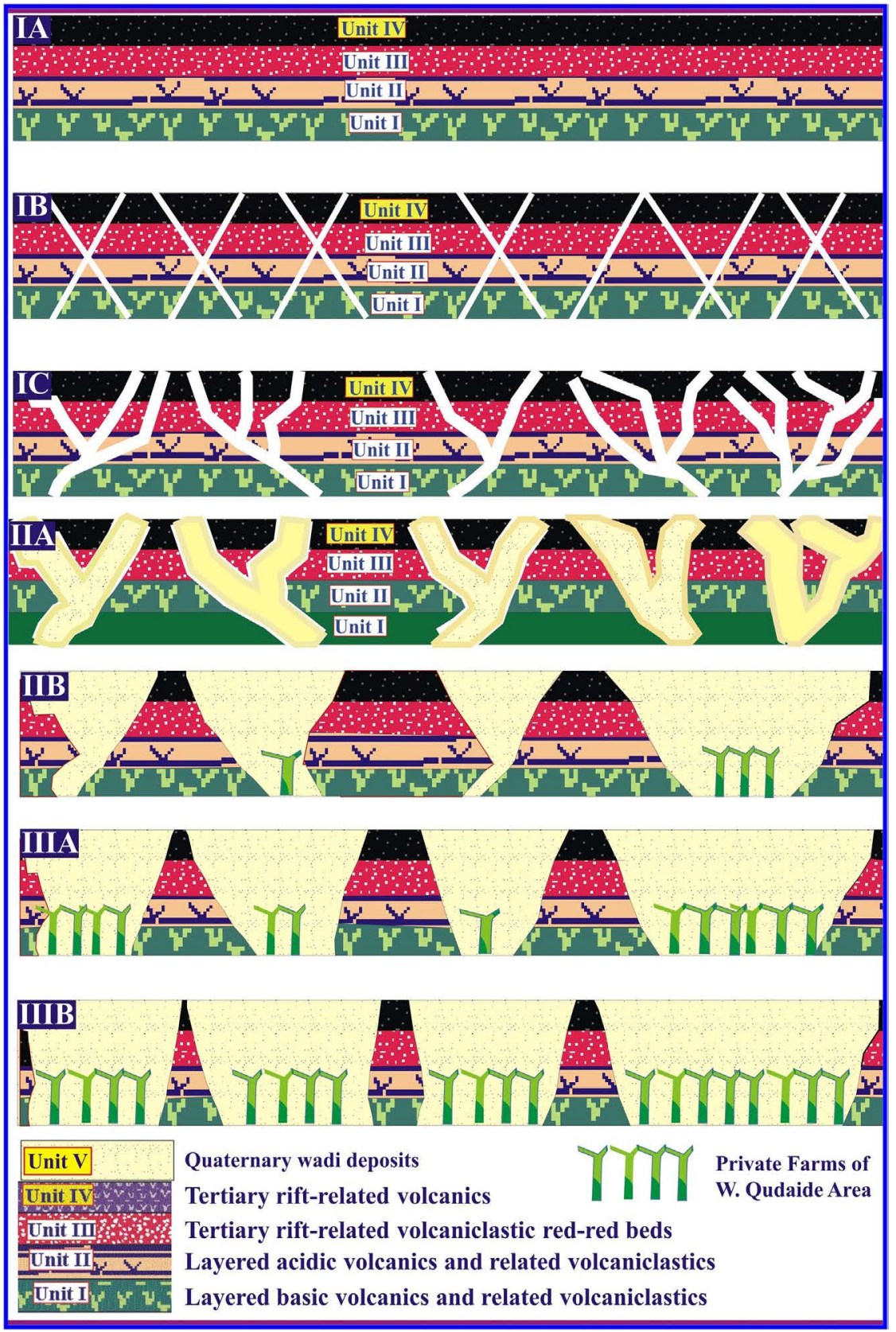

Figure 18. Schematic diagrams showing the different stages of landforms evolution of Wadi Qudaid area. (IA), (IB), (IC) Initial stages of landforms evolution; (IIA), (IIB) Progressive stages of landforms evolution; (IIIA), (IIB) = Ultimate stages of landforms evolution.

destruction of this basaltic sheet after its formation [16]. At this stage, the wadies become wider and the interfluves become narrower (Figure 18(IIA), Figure 18(IIB)). On the satellite images, this stage of landforms evolution may lead to the destruction and removal of the topmost basalts which led to the exposing of the underlying softer units (Figure 20(IIa1), Figure 20(IIa2), Figure 20(IIb1), Figure 20(IIb2)). The progress of weathering processes led the reduction of the hill side slopes as well as the reduction of their elevation which resulted in the formation of wide interfluvial areas with very small hills of gentle slope and low 
elevation (initial stages of peniplanation processes). This stage of evolution is well represented in the middle part of Wadi Qudaid (Figure 20(IIb1), Figure 20 (IIb2)). In this part of the wadi, the residual landforms become elongated and dissected into smaller parts. The complete removal of the hard basaltic sheet from the topmost parts of these elongated ridges led to the exposing of the low lying schists of Samran Group (Figure 20(IIb2)).

The continuous stripping out of the basaltic sheet and the underlying Tertiary sedimentary succession by slope and scarp retreat (Figure 21(IIa1), Figure 21(IIIa2)).

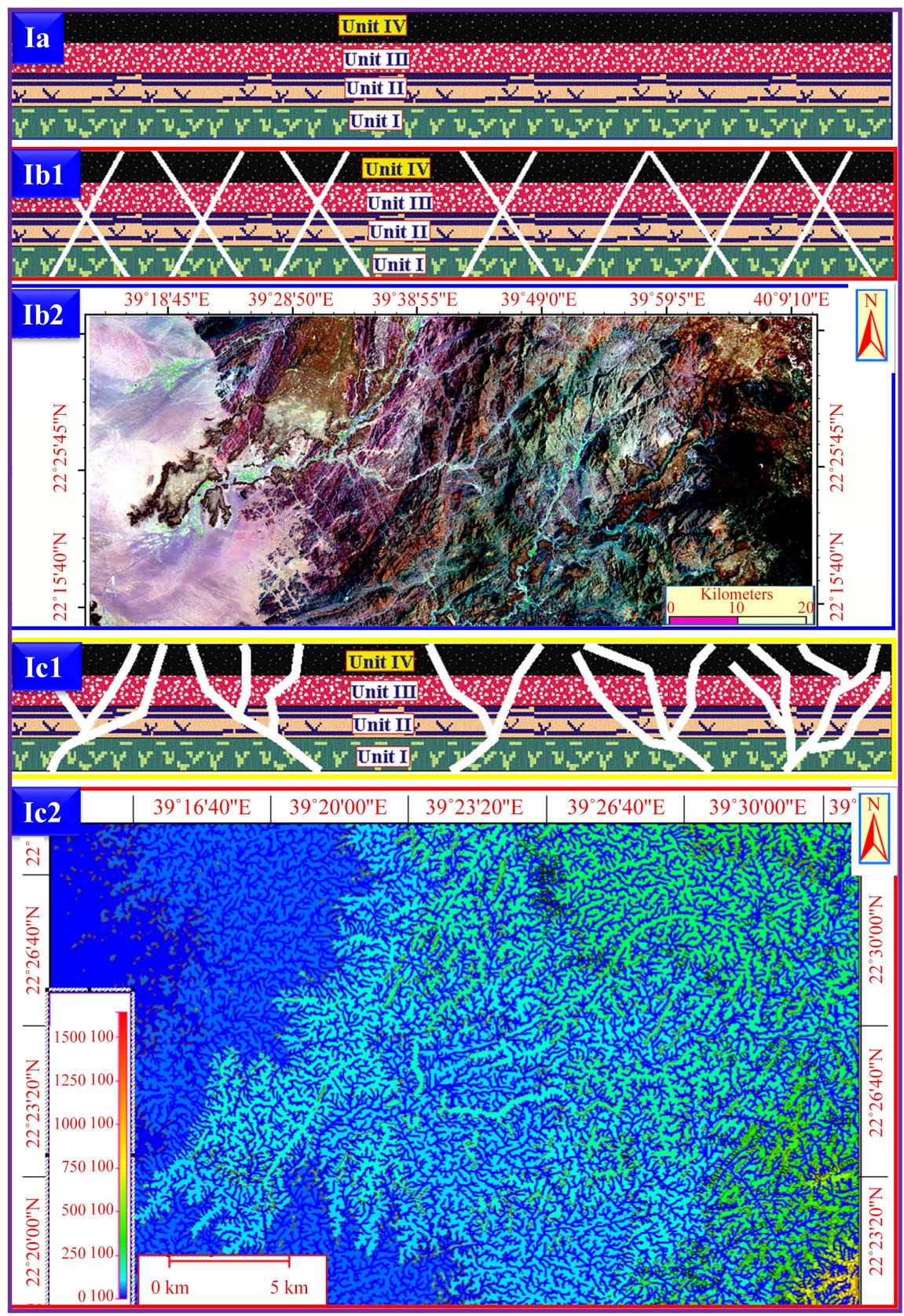

Figure 19. (Ia), (Ib1), (Ib2), (Ic1), (Ic2) Schematic diagrams and the equivalent satellite and drainage lines images that illustrate the different sub-stages of the initial stage of evolution of landforms. 


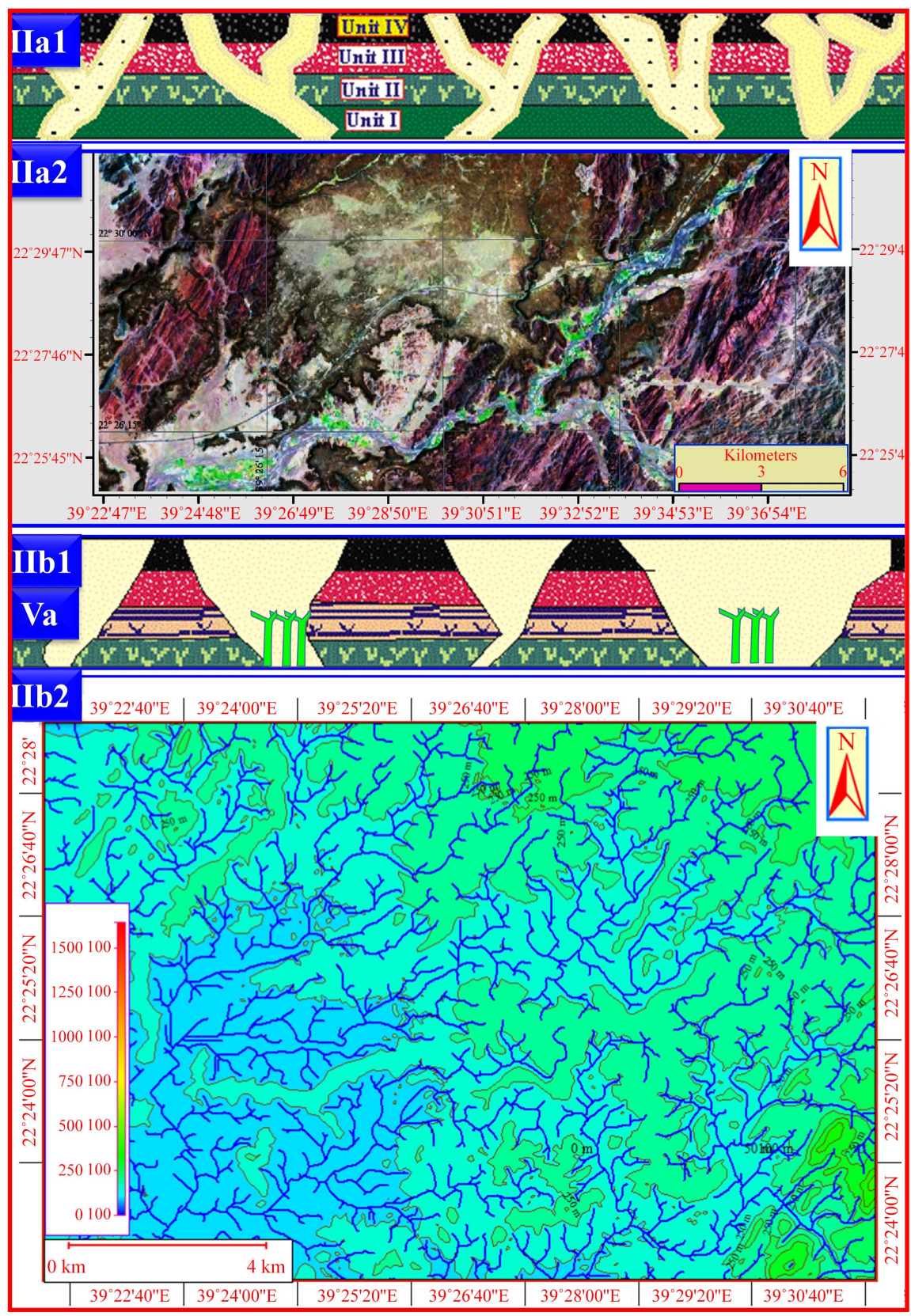

Figure 20. (IIa1) (IIa2) (IIb1) (IIb2) Schematic diagrams, and the equivalent satellite and drainage lines images that illustrate the different sub-stages of the etchplanation and pedimentation sub-stage of evolution of landforms.

The continuation of the retreat of slope led to the further consumption of the wide interfluves and the development of large inselbergs and ridges. The absence of residual landforms within the floor of some areas within the wadi course represents an advanced stage of dissection and stripping of the basaltic sheet and the underlying volcano-sedimentary succession. The dissection of the hard-basaltic sheet and the distribution of the residual landforms appears to be controlled by the NE, E-W, and NW faults and the associated fracture sets (Figure 19(Ic1) and Figure 20(IIb2)). 


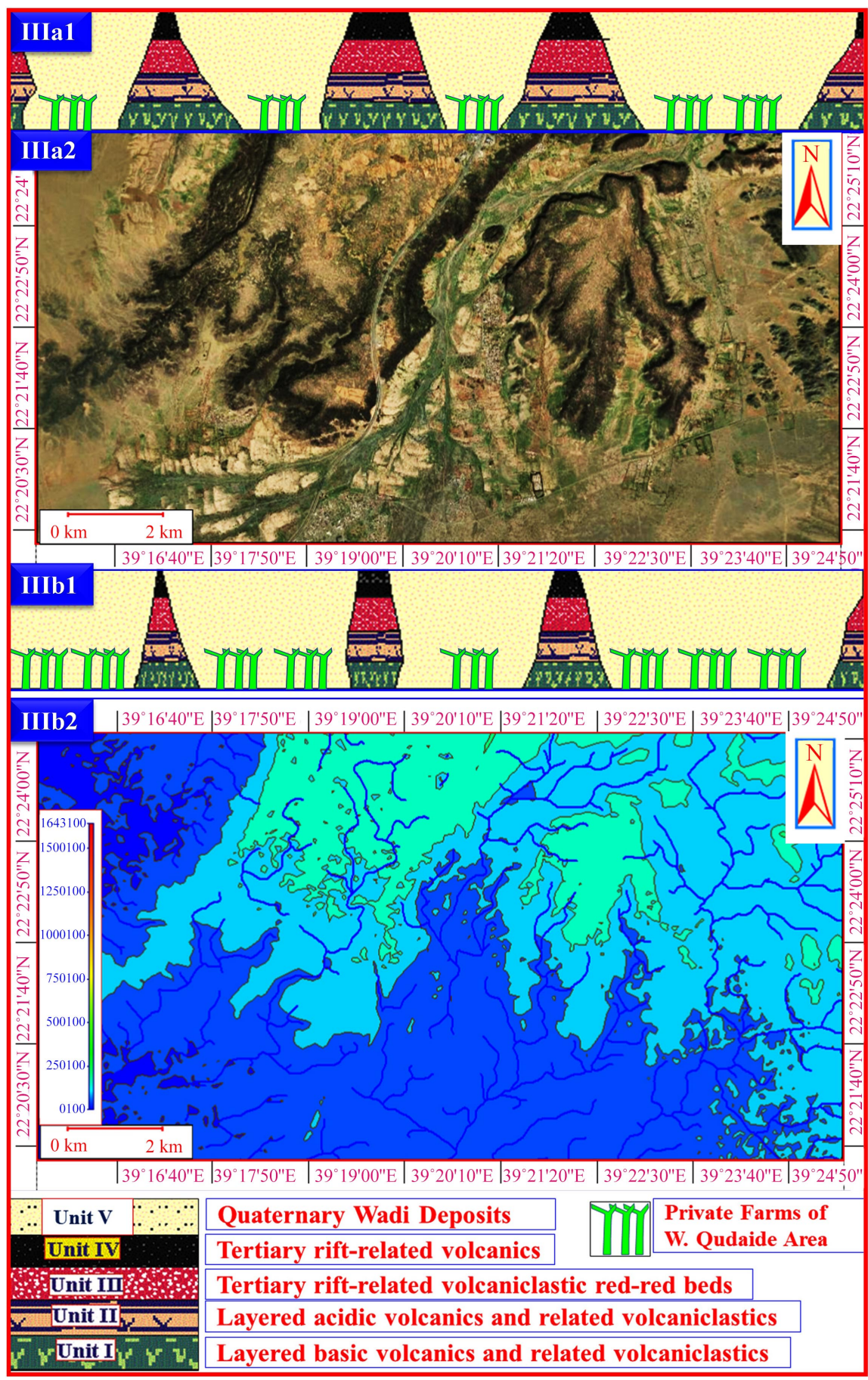

Figure 21. (IIIa1) (IIIa2) (IIIb1) (IIIb2) Schematic diagrams, and the equivalent satellite and drainage lines images that illustrate the different sub-stages of the peneplanation sub-stage of evolution of landforms.

The bore hole data of hydrogeology and hydrochemistry study published by [9]. They revealed that the wadi fills Quaternary deposits are present truncated different rock units i.e. the layered basic and acidic volcanics and related volcaniclastics, the Tertiary volcaniclastic red beds, and the topmost basaltic sheet. This indicates the progressive weathering and erosion of the different levels be- 
fore the final stage of wadi fill accumulation.

Ultimate stages of denudation and erosion accompanied by the progressive removal of the destructed materials by wind and current actions (Figure 21(IIIa1), Figure 21(IIIa2), and Figure 21(IIIb1), Figure 21(IIIb2)). This led to the reduction of the wide interfluves into small areas. During this stage, the pediments become wider and the formed residual landforms are still of the same slope angles and also of the same elevations, pedimentation stages). Smaller tributaries to Wadi Qudaid are few with gentle gradients. The final stages of the landform's evolution of Wadi Qudaid were finished by the last long humid time periods that dominated in Saudi Arabia. After that time, the wadi course is probably occupied by streams meander freely over vast floodplains showing natural levees, oxbow lakes, etc. the interfluves area becomes broad and flat with lakes, swamps and marshes.

The dominant alternating humid and arid periods led to 1) evaporation and deposition of playa deposits and salt crusts and, 2) wind abrasion and deposition, the wide flood plains of silts and clays represent the main cultivated lands in the wadi course. The main problems in this area are related to the effect of natural hazards, which include:

1) The strong wind actions and wind storms (especially in summer times) led to partial desertification and the destruction of many cultivated private farms and loss of many crops.

2) The flood time periods which resulted in the destruction of the main roads of the wadi area as well as the destruction of villages and farms. This is accompanied by the formation of new channel lag longitudinal conglomerate bars and also the build up of the new flood plain of silts and clays.

3) The quarrying processes for concrete, gravel within the course of Wadi Qudaid led the change and the natural topography of the wadi floor.

4) The haphazard drilling of water wells which resulted in the lowering of the groundwater level of the study area.

\section{Discussions and Conclusions}

Deserts on old creations, occurring in the Indian subcontinent, Africa, Arabia and Australia, have less relief than the Atacama, but are not necessarily a dune-covered land with low relief. The landform on such a geological framework is produced by processes of erosion and deposition carried out by both water and wind. The surface material includes bare rock, gravel, sand and riverine silt. According to [17] the rainfall in arid regions rainfall is localized, intense and erratic over both time and space. Widespread rain occurs only when unusual meteorological incidents occur.

Three main concepts are previously postulated for the describing the mechanism of erosion processes and formation of depressions, wadies, lateritic products and karst landforms and the formation of the lower erosion surface from the higher older surface is described as etchplanation [18], and the related processes 
of surface weathering are called etching. The term etchplain or etched plain was first introduced and described by [18]. He defined the etchplain as a plain formed by alternate deep weathering and stripping. The concept of etchplanation has attracted the attention of several authors in explaining the landform evolution in humid tropics [19] [20]. According to [16], the nature of etch surface depends upon the following: 1) the lithology and structure of the local rocks; 2) the intensity of erosion into the older surface and, 3) the surficial configuration of the lower surface. Two main erosion surfaces are recognized in the study area. i.e. old erosion surface on the top of the highlands (Tertiary harrat or Arabian shield rocks) and that separated from the younger erosion surface (floor or the main course of Wadi Qudaid) by scarps with typical four hill slope elements of [14] the waxing slope (upper convexity), the cliff (free face), the debris (constant) slope and the pediment (lower concavity or waning slope). The presence of the scarp and plateau at nearly the same elevation of the summits of residual cone hills and ridges separated from the scarp indicates that these residual landforms are remnants of previous continuous erosion surface. Running water, both as sheet and channelized flow, is the prominent geomorphic process in rock deserts. The water is derived from rain on the mountains or cloudbursts, as described earlier. Given the nature of rainfall in the arid tropics, these ephemeral channels mostly remain dry, being in flood for an extremely brief period of time. One common observation in all papers dealing with stream channels in arid areas is the episodic widening and filling of desert channels [21] [22]. The present study of the landforms of Wadi Qudaid revealed that these landforms have been formed by multiple cycles of deep weathering processes under certain paleo-topographic and paleoclimatic controls. The presence of the study area in the west central part of the Arabian shield rocks and the very high regime of tectonic events dominated during the rifting and opening of the Red Sea facilitate the denudation processes and the formation of the completely peniplained areas in the downstream (Southwestern) part (younger erosion surface). The highlands of the upstream (northeastern) part of Wadi Qudaid are still in the immature stage of the erosion cycle as a result of the change of climatic conditions from humid to present day and semi-arid. The variation in the groundwater quality was studied by [23]. They concluded that the groundwater of the upstream part is of better quality than the downstream part.

Although the processes of erosion and landforms evolution led to the formation of wide peneplain areas suitable for the human population and urban extension, there is many highways are constructed in the middle part of the wadi. These roads are continuously removed as a result of the annual sheet floods and also the change in the course of these floods. Also, many human populations are present in the main course of the wadi which is annually subjected to the sheet floods. The private farms in the middle part of Wadi Qudaid are annually subjected to damaging by the sheet flood. The main lineaments and faults of the study area must be taken into consideration in the future population planes. 


\section{Conflicts of Interest}

The authors declare no conflicts of interest regarding the publication of this paper.

\section{References}

[1] Abdulrazzak, M.J., Sorman, A.U. and Rizaiza, O.A. (1988) Estimation of Natural Groundwater Recharge under Saudi Arabian Arid Climatic Conditions, Estimation of Groundwater Recharge. D. Reidel Publishing Company, Boston, 125-138. https://doi.org/10.1007/978-94-015-7780-9_8

[2] Basmaci, Y. and Al-Kabir, M. (1988) Recharge Characteristics of Aquifers of Jeddah-Makkah-Taif Region. Mathematical and Physical Sciences, 222, 367-375. https://doi.org/10.1007/978-94-015-7780-9_23

[3] Basmaci, Y. and Hussein, J.A.A. (1988) Groundwater Recharge over the Western Saudi Arabia. Mathematical and Physical Sciences, 222, 395-403. https://doi.org/10.1007/978-94-015-7780-9_25

[4] Abu-Rizaiza, O.S., Sarikaya, H.Z. and Ali-Khan, M.Z. (1989) Urban Groundwater Rise Control: Case Study. Journal of Irrigation and Drainage Engineering, 115, 588-607. https://doi.org/10.1061/(ASCE)0733-9437(1989)115:4(588)

[5] Sorman, A.U. and Abdulrazzak, M.J. (1993) Infiltration-Recharge through Wadi Beds in Arid Regions. Hydrological Sciences Journal, 38, 173-186. https://doi.org/10.1080/02626669309492661

[6] Gutub, S.A. and Awadalla, S.A. (1994) Numerical versus Field Studies of Delayed Yield in Response to a Moving Water-Table. Hydrological Processes, 8, 429-435. https://doi.org/10.1002/hyp.3360080505

[7] Onder, H. (1994) Non-Steady-Flow Type Curves for Strip Aquifers with Constant Drawdown. Journal of Irrigation and Drainage Engineering, 120, 732-741. https://doi.org/10.1061/(ASCE)0733-9437(1994)120:4(732)

[8] Shehata, W., Banakher, K., Shouman, S. and Al Solami, A. (2001) Suggested Plan to Dispose the Wastewater of Jeddah, Saudi Arabia, Saudi Geological Survey.

[9] Sonbul, A.R., Sharaf, M.A. and Mesaed, A.A. (2017) Hydrogeology of Wadi Qudaid Area, Northeast Jeddah, West Central Arabian Shield, Saudi Arabia. Open Journal of Geology, 7, 1749-1766. https://doi.org/10.4236/ojg.2017.712117

[10] Alghamdi, M.A.M. (2003) Suitability of Sedimentary Formations around Jeddah for Disposal of Short-Lived Radioactive Wastes. Unpublished PhD Faculty of Earth Sciences, King Abdulaziz University, Jeddah, 346 p.

[11] Johnson, P.R. (2006) Explanatory Notes to the Map of Proterozoic Geology of Western Saudi Arabia. Technical Report SGS-Tr-2006-4, 107C, 1:250,000 Scale.

[12] Al Wash, M.A. and Zakir, F.A.R. (1992) Tectonic Analysis of the Jeddah Taif Area on the Basis of Landsat Satellite Data. Journal of African Earth Sciences, 15, 293-301. https://doi.org/10.1016/0899-5362(92)90076-O

[13] Moore, T.A. and Al-Rehaili, M.H. (1989) Geologic Map of the Makkah Quadrangle, Sheet 21D, Kingdom of Saudi Arabia. Ministry of Petroleum and Mineral Resources, Deputy Ministry for Mineral Resources Publication, Jeddah.

[14] King, L.C. (1962) Morphology of the Earth. Oliver and Boyd, Edinburgh.

[15] Sharp, R.P. (1982) Landscape Evolution (A Review). Proceedings of the National Academy of Sciences of the United States of America, 79, 4477-4486. https://doi.org/10.1073/pnas.79.14.4477 
[16] Faniran, A. and Jeje, L.K. (1983) Humid Tropical Geomorphology. Longman, London, Lagos, New York, xvii +414 p.

[17] Gupta, A. (2012) Tropical Geomorphology. Cambridge University Press, Cambridge. https://doi.org/10.1017/CBO9780511978067

[18] Wayland, E.J. (1934) Peneplains and Some Erosional Landforms. Geol. Surv. Uganda. Ann. Rep. Bull., 1, 77-79.

[19] Budel, J. (1957) Die "Doppelten Einebnungstlachen" in den feuchten Tropen. Zeitschrift für Geomorphologie N.F., 1, 201-228.

[20] Thomas, M.F. (1989) The Role of Etch Processes in Landform Development. I: Etching Concepts and Their Applications, II: Etching and the Formation of Relief. Zeitschrift für Geomorphologie N.F., 33, 129-142 and 257-274.

[21] Schick, A.P. (1988) Hydrological Aspects of Floods in Extreme arid Environments. In: Baker, V.R., Kochel, R.C. and Patton, P.C., Eds., Flood Geomorphology, Wiley, New York, 189-203.

[22] Bourke, M.C. and Pickup, G. (1999) Fluvial Form Variability in Arid Central Australia. In: Miller, A.J. and Gupta, A., Eds., Varieties of Fluvial Form, Wiley, Chichester, 249-271.

[23] Sharaf, M.A., Sonbul, A.R. and Mesaed, A.A. (2018) Geochemical Variation of the Groundwater Characters along Wadi Qudaid, Northeast Jeddah, West-Central Arabian Shield, Saudi Arabia. Arabian Journal of Geosciences, 11, 470.

https://doi.org/10.1007/s12517-018-3766-1 